\title{
EDUCATION CHOICES IN ETHIOPIA: WHAT DETERMINES WHETHER POOR HOUSEHOLDS SEND THEIR CHILDREN TO SCHOOL ${ }^{1}$
}

\author{
Tassew Woldehanna ${ }^{2}$, Alemu Mekonnen, and \\ Nicola J ones ${ }^{3}$
}

\begin{abstract}
The paper uses data from a 2002 survey of 1000 rural and urban households with eight-year old children sampled from food insecure communities in Tigray, Amhara, Oromia, SNNP and Addis Ababa Regional States. Using a probit regression model, we investigated external factors associated with child enrolment in school. We found that household wealth, cognitive social capital, adult education and ownership of land had a positive impact on whether eight-year-old children were attending school. Household wealth had the strongest impact followed by cognitive social capital (perceived levels of trust and reciprocity), the maximum level of education attained by female adults in the household, ownership or rental of land, and the maximum level of education attained by male adults in the household. In contrast, child enrolment was found to be negatively associated with the number of household members over the age of 15 years, birth order, ownership of livestock, economic shocks, distance to primary school, and child labour, in declining magnitude. The findings in general suggest that increasing child enrolment in primary school, which is a commitment of the Sustainable Development and Poverty Reduction Program (SDPRP) and Education Sector Development Program (ESDP), will necessitate more targeted educational policies to address regional, gender and wealth disparities, the development of education programmes for adult caregivers, as well as broader intersectoral policy initiatives to ensure that policy initiatives in other sectors facilitate rather than hinder children's education (particularly credit and labour markets and infrastructure-related policies).
\end{abstract}

\footnotetext{
${ }^{1}$ The final version of this article was submitted in January 2009.

${ }^{1}$ The research is conducted by the Young Lives Ethiopia project financed by the UK Department for International Development (DFID). The research project is housed under the Ethiopian Development Research Institute (EDRI), Ethiopia, while the dissemination part of the project is administered by Save the Children UK, in Ethiopia and in London. The Young Lives project is an international study of child poverty with a longitudinal panel survey that follows nearly 12,000 children and their families over 15 years in four countries, namely Ethiopia, Peru, Vietnam and India. All errors and opinions expressed are those of the authors.

${ }^{2}$ Department of Economics, Addis Ababa University, Ethiopia

Contact address: Tassew Woldehanna, Department of Economics, Addis Ababa University wtassew@ethionet.et

${ }^{3}$ Save the Children UK, London
} 


\section{Introduction}

Ethiopia has one of the lowest primary school enrolment rates and one of the highest illiteracy rates in the world. Finding appropriate mechanisms through which to address this has long been an economic, social and political challenge for the government. When the current government took power in 1991, the Ethiopian education system was suffering from a lack of 'relevance, accessibility and equity' (MoE, 1994). These three problems underpin all education policy debates in the country, and are related to the policy-related weaknesses of past governments. During the imperial period (1941-74) the education system emphasised modernisation and focused on expanding secondary education, but expansion, of both primary and secondary education, was limited to urban centres. By contrast, the socialist regime (1974-1990) aimed at expanding primary education to the rural areas by constructing schools in every kebele (the lowest administrative unit). However, the education sector was stretched to the limit with no additional available resources, and, as a result, the quality of education was compromised, rendering the education provided of limited relevance (MoE, 1994)).

Although there has been a remarkable improvement in the rate of primary school enrolment during the last decade (from $35 \%$ in $1997 / 8$ to $85.8 \%$ in 2005/6), there are still wide disparities between regions; the overall ratio of boys to girls is still high in rural areas (approximately 20 percentage points although there are marked regional variations); the urban/rural difference is still significant ; many concerns about the quality of education persist and the primary completion rate is significantly lower than primary enrolment (MoE, 2007).

In order to solve these problems and in recognition of the instrumental role that education plays in social development and poverty reduction (MoE 1994), the first multi-year Education Sector Development Plan (1997) initiated a range of programmes. These included increasing the number of and upgrading existing school buildings ${ }^{4}$, expanding teacher training programs, introduction of automatic promotion for grades 1-3, use of local languages as the teaching medium, development of context-appropriate primary school syllabi and textbooks ${ }^{5}$, and the elimination of school fees. Quality assessment mechanisms have also been introduced: a Minimum Learning Competency Guideline (MLCG) and a National

\footnotetext{
${ }^{4}$ In order to cater to the special needs of pastoral communities, there is a plan to build boarding schools and hostels in Afar, Somali, Benishangul Gumuz, SNNPR and Oromia regions. Low cost schools and multigrade village schools will be established in settlement areas.

5 The EDSP stated that the Ministry of Education would aim to print and distribute a total of 37.4 million textbooks in order to attain a student-textbook ratio of one-to-one.
} 
Education Assessment (NEA) are being developed to assess standards at each level in all subjects.

These policy efforts notwithstanding, the first Ethiopian Educational Sector Development Programme (ESDP I) midterm review report shows that while progress has been made in expanding enrolment, educational quality has deteriorated, particularly in terms of the curriculum (which sacrifices breadth for depth). For example, while gross enrolment in grades 1-8 has increased from 34.7 per cent in $1996 / 97$ to 85.8 per cent in $2005 / 06$, on the other side, the drop-out rate for the same grades (1-8) for the year 2005/06 was 11.8 per cent (MoE, 2007). The problem of school dropout was more serious in rural areas than urban areas. Around 13.6 percent of the primary school pupils in rural areas have dropped out during the reference year. This has become a puzzle for the education sector in that while enrolment is growing, poor retention is off-setting the gains and resulting in a continued disparity between gross enrolment rates and primary completion rate (ibid.).

Financing concerns further exacerbate efforts to address Ethiopia's educational crisis. The sector is heavily dependent on external assistance, making it vulnerable to changes in donor policy, delays in transferring funds and failure to fulfil commitments ${ }^{6}$. That is, although the government officially allocates 13.4 per cent of its total expenditure to education, it has been able to cover only 64 per cent of the total education budget for the period 2002/03-2004/05. For the rest, it relies on Heavily Indebted Poor Countries (HIPC) debt relief (3.6 per cent), available and expected external loans and assistance (10.3 per cent) and community contributions of 1.6 per cent (MoE, 2002). That is, the education sector budget deficit amounts to 31.4 per cent.

Given these problems, the likelihood of achieving the EDSP's goal of achieving Millennium Development Goal Number 2 of universal primary education by 2015 through the current formal education system seems high. It is therefore essential that other alternatives are explored. While much effort has been put into increasing accessibility to education from the supply side, not much emphasis has been given to the out-of-school factors that influence access to school. The objective of this paper is, therefore, to establish a link between micro-level outcomes and macro-level policy initiatives with respect to primary school enrolment and poverty reduction, and to investigate the relative importance of factors associated with child enrolment. The paper specifically deals with the relatively under-researched external (household and

\footnotetext{
${ }^{6}$ While donors transferred only 50 per cent of what they had committed, the government has fulfilled all its budget commitments (MoE, 2001).
} 
community-level) factors affecting child enrolment (such as lack of income, child labour, economic shocks, social capital and parents' education) as opposed to internal (school-related) factor such as improving the quality of teachers and the syllabus of primary grades. By drawing on the Young Lives sample of 1,000 eightyear-olds from 20 sentinel sites (20 locations in 12 rural and 8 urban areas ), it will contribute a more comprehensive analysis of the determinants of child school enrolment in Ethiopia. Specifically, it will analyse the relative importance and interactive impact of economic, infrastructural, educational and household composition factors, as well as three key issues that have not been discussed in the literature to date: the relative importance of the average level of education of female compared to male adults in the household; the interactive impact of economic shocks on household livelihoods and child enrolment (which may hinder households' capacity to invest in child schooling); and social capital.

The paper is organised as follows. In section two the literature review begins with a brief overview of child primary school enrolment and the key education policies in Ethiopia. It then provides a thematic review of the key factors influencing child enrolment in the developing world and specifically in Ethiopia. The methodology of the paper is described in section three. Section four presents the descriptive statistics and the results of the univariate and multivariate analyses drawing on the livelihoods framework $^{7}$ on the determinants of child enrolment. Finally, a summary of the results and their policy implications are provided in section five.

\section{Literature review}

\subsection{School enrolment status of Ethiopian children}

Although primary school enrolment has been increasing in recent years, Ethiopia still has one of the lowest enrolment rates in the developing world, even by sub-Saharan African standards, as seen in Table 1 below. ${ }^{8}$ Moreover, enrolment rates decline significantly as the school grade level increases (Table 2).

\footnotetext{
${ }^{7}$ The Sustainable Livelihoods Framework is based on the assumption that individuals and households aim at sustaining their livelihoods through maintaining or increasing their assets (which can include financial, human, social and natural capital). Poverty can, thus, be seen as a situation in which an individual or a household fails to maintain their assets and becomes vulnerable to shocks. The framework emphasises the centrality of assets, rather than capital, in understanding poverty. (Lockwood, 2001)

8 Although enrolment rates are improving (admittedly from a low base), the level of enrolment per se does not guarantee that there will be an improvement in education unless it is matched by sustainable quality of education. Evidence suggests that the quality of education (at all levels) was deteriorating until 2001 and the dramatic increment in enrolment since then (though still low compared to other countries) has resulted in further deterioration in output (for details see Befekadu et al, 2001: 258-96; Befekadu and Birhanu, 2000: 116-18;).
} 
Table 1: Trend in GPER 1970-1996 and NPER 1999

\begin{tabular}{lcccccc}
\hline \multirow{2}{*}{ Region } & $\mathbf{1 9 7 0}$ & $\mathbf{1 9 8 2}$ & $\mathbf{1 9 9 3}$ & $\mathbf{1 9 9 6}$ & \multicolumn{2}{c}{1999} \\
\cline { 2 - 7 } & GPER & GPER & GPER & GPER & GPER & NPER \\
\hline Developing countries & 79 & 95 & 107 & 108 & - & - \\
East Asia and Pacific & 88 & 111 & 118 & 118 & 106 & 92 \\
Latin America and Caribbean & 99 & 105 & 109 & 114 & 132 & 97 \\
Middle East and North Africa & 68 & 91 & 95 & 94 & 94 & 83 \\
South Africa & 67 & 77 & 97 & 101 & 101 & 79 \\
Sub-Saharan Africa & 50 & 74 & 68 & 74 & 79 & 54 \\
Ethiopia & 16 & 36 & 26 & 35 & 59 & 34 \\
\hline
\end{tabular}

Source: Befekadu et al, 2002; GPER: gross primary enrolment ratio; NPER: net primary enrolment ratio ${ }^{9}$

Available evidence also indicates that there are wide differences between rural and urban areas and between sexes (Mulat, 1997; Befekadu et al 2002; Seyoum, 1997). In 1995/96, 91 per cent of eligible students at primary level were enrolled in urban areas, while the corresponding figure for rural areas was only 18 per cent (Mulat, 1997). The significant difference in participation rate between males and females (Table 2) is attributed to, among others, religious and traditional values and practices that discourage female education. These factors are more widely observed in rural areas (Mulat, 1997; Seyoum, 1997).

Table 2: Participation in education (as percentage of relevant age groups)

\begin{tabular}{lcccccc}
\hline \multirow{2}{*}{ Academic year } & \multicolumn{3}{c}{ Primary } & \multicolumn{3}{c}{ Secondary } \\
\cline { 2 - 7 } & Males & Females & Total & Males & Females & Total \\
\hline $2001 / 02$ & 71.7 & 51.2 & 61.6 & 20.4 & 13.7 & 17.1 \\
$2002 / 03$ & 74.6 & 53.8 & 64.4 & 24 & 14.3 & 19.3 \\
$2003 / 04$ & 77.4 & 59.1 & 68.4 & 28.2 & 15.9 & 22.1 \\
$2004 / 2005$ & 88 & 71.5 & 79.8 & 34.6 & 19.8 & 27.3 \\
$2005 / 2006$ & 98.6 & 83.9 & 91.3 & 41.6 & 24.5 & 33.2 \\
\hline
\end{tabular}

Source: Educational statistical abstracts (MoE, various years).

There are also considerable regional differences with regard to the growth in enrolment during the years 1995 - 2005, both in terms of absolute number of primary school enrolments and GPER (see Table 3). Given such wide variation, the national average of GPER is somewhat misleading. More specifically, in terms of percentage changes between 1995 and 2005, the regions with highest achievement were Amhara (382.68 per cent), Oromia (323.58 per cent), Benshangul Gumuz (209.89 per

\footnotetext{
${ }^{9}$ Gross primary enrolment ratio is the total number of children in primary school as a proportion of children of official primary school age; net primary enrolment ratio is the total number of children enrolled who are of official school age for that level, as a percentage of the population of official school age for that level. GPER in excess of 100 per cent can be indicative of discrepancies in school and census data, late enrolment in school or children repeating years.
} 
cent) and SNNP (197.22 per cent), where GPER in 2001 was more than triple that of 1995. In contrast, Harari (93.07 Percent) and Addis Ababa (74.91 per cent) are regions with low performance. The comparatively low annual growth in Harari and Addis Ababa is primarily due to high initial enrolment (53.4 and 84.9 per cent respectively).

Table 3: Comparison of relative achievement in GPER across regions (\%)

\begin{tabular}{lcccc}
\hline \multicolumn{1}{c}{ Region } & GPER 1995 & GPER 2005 & $\begin{array}{c}\text { Change } \\
\mathbf{1 9 9 5 - 2 0 0 5}\end{array}$ & $\begin{array}{c}\text { Average annual } \\
\text { growth rate 1995-2005 }\end{array}$ \\
\hline Tigray & 43.7 & 100.9 & 130.89 & 13.09 \\
Afar & 8.4 & 21.9 & 160.71 & 16.07 \\
Amhara & 17.9 & 86.4 & 382.68 & 38.27 \\
Oromia & 21.2 & 89.8 & 323.58 & 32.36 \\
Somali & 11.6 & 30.3 & 161.21 & 16.12 \\
B/Gumuz & 35.4 & 109.7 & 209.89 & 20.99 \\
SNNP & 28.8 & 85.6 & 197.22 & 19.72 \\
Gambella & 53.9 & 137.1 & 154.36 & 15.44 \\
Harari & 53.4 & 103.1 & 93.07 & 9.31 \\
Addis Ababa & 84.9 & 148.5 & 74.91 & 7.49 \\
Dire Dawa & 41.0 & 79.5 & 93.90 & 9.39 \\
Regional total & 26.2 & 85.8 & 227.48 & 22.75 \\
\hline
\end{tabular}

Source: Educational statistical abstracts (MoE, various years) and own computation

The net primary enrolment ratios are higher for urban areas than for rural areas in all regions as seen in Table 4. Although nationally, there are still more boys enrolled than girls in rural areas, gender differences across regions were surprisingly mixed. In Tigray and Amhara regions the female enrolment rate was higher than that for males in rural areas. In Amhara, Tigray and Benishangul, female NPER was slightly higher than that of their male counterparts in urban areas, but significantly lower in rural areas in Afar, Oramia, Somali, Benishangul, SNNP, Harari, Addis Ababa and Dire Dawa.

Although clearly more research is needed to understand these regional disparities ${ }^{10}$, part of the variation appears to be explained by distance to school. The 1999 Welfare Monitoring Survey (MoFED, 2002b) indicated that while the average distance to elementary schools for the country is 1.7 kilometres, and only one region, Somalia, has more than $3 \mathrm{KM}$ mean distance to primary school. The figures are higher for rural areas than for urban areas. Regional variation, which is presented in Table 2.5, is relatively small, except for Somali where the mean distance from primary schools to household residences is $6.4 \mathrm{~km}$ greater than the region with the next highest distance. At the opposite end of the scale are the urban regions, like Addis Ababa,

${ }^{10}$ Forthcoming work by Young Lives based on 2005 fieldwork will attempt to analyze some of the factors involved. 
Harari and Dire Dawa, with a mean distance of around one kilometre. However, compared to 1999, there has been a marked improvement in the year 2004. The average distance to a primary school in 1999 for the whole country was $3 \mathrm{~km}$, while for rural areas the figure was $3.8 \mathrm{~km}$ and a quarter of the total Ethiopian population was living 3 or more kilometres away from primary schools.

Table 4: Net primary enrolment rate in Ethiopia 2004 (by region, residence and sex)

\begin{tabular}{lccccc}
\hline \multirow{2}{*}{ Region } & \multicolumn{5}{c}{ NPER } \\
\cline { 2 - 6 } & \multicolumn{2}{c}{ Urban } & \multicolumn{4}{c}{ Rural } \\
\cline { 2 - 6 } & Male & Female & Male & Female & All \\
\hline Tigray & 83.99 & 87.44 & 38.4 & 47.35 & 49.83 \\
Afar & 68.03 & 60.41 & 24.27 & 19.15 & 33.9 \\
Amhara & 84.09 & 86.23 & 32.74 & 38.95 & 40.1 \\
Oromia & 81.94 & 81.1 & 42.58 & 33.59 & 42.45 \\
Somali & 65.8 & 52.4 & 11.74 & 5.94 & 22.76 \\
Benishangul & 72.24 & 74.15 & 48.12 & 32.36 & 44.69 \\
SNNP & 73.75 & 67.91 & 41.13 & 30.53 & 39.01 \\
Gambella & - & - & - & - & - \\
Harari & 89.07 & 82.99 & 60.14 & 34.7 & 67.49 \\
Addis Ababa & 88.32 & 79.66 & 53.28 & 47.86 & 82.95 \\
Dire Dawa & 80.99 & 72.7 & 47.12 & 25.83 & 62.55 \\
Ethiopia & 81.94 & 79.37 & 39.18 & 34.96 & 42.49 \\
\hline Source: CSA: WMS (2004) & & & &
\end{tabular}

Table 5: Mean distance to reach public schools in 1999 and 2004 by region

\begin{tabular}{lrccc}
\hline \multirow{2}{*}{ Region } & \multicolumn{2}{c}{1999} & \multicolumn{2}{c}{ 2004 } \\
\cline { 2 - 5 } & $\begin{array}{c}\text { Primary } \\
\text { school }\end{array}$ & $\begin{array}{c}\text { Secondary } \\
\text { school }\end{array}$ & $\begin{array}{c}\text { Primary } \\
\text { school }\end{array}$ & $\begin{array}{r}\text { Secondary } \\
\text { school }\end{array}$ \\
\hline Tigray & 3.44 & 20.89 & 1.27 & 9.51 \\
Afar & 4.6 & 29.41 & 1.34 & 30.76 \\
Amhara & 3.23 & 22.69 & 2.37 & 19.63 \\
Oromia & 3.16 & 20.46 & 1.59 & 20.15 \\
Somali & 3.93 & 20.95 & 8.77 & 44.67 \\
Benishangul & 3.13 & 20.92 & 2.2 & 32.66 \\
SNNPR & 2.63 & 15.1 & 1.05 & 14.02 \\
Gambella & 2.43 & 12.03 & & \\
Harari & 0.93 & 5.05 & 0.13 & 1.81 \\
Addis Ababa & 0.86 & 1.93 & 0.58 & 1.3 \\
Dire Dawa & 1.14 & 7.64 & 1 & 11.62 \\
Ethiopia & 3 & 19.25 & 1.72 & 18.18 \\
Rural & 3.8 & 21.9 & 2.01 & 20.85 \\
Urban & 0.73 & 3.47 & 0.72 & 6.74 \\
\hline Source: MoFED $2002 ;$ CSA 2004 & & &
\end{tabular}

Source: MoFED 2002; CSA 2004. 


\subsection{Determinants of child school enrolment}

The literature on access to child schooling in developing countries has placed varying emphases on (a) economic factors, including the level of household income, vulnerability to household economic shocks and the use of child labour, (b) the accessibility of schools in terms of time and cost of travel as well as safety (especially for girl children), (c) the relative importance of parental education, (d) household composition, as well as perceived usefulness of schooling, whereby parents are often willing to make enormous sacrifices for schooling they feel will give their children a better future. Each of these is now discussed.

\section{Economic factors}

The decision whether or not to send a child to school depends on the direct and indirect costs involved for the household (see Mulat, 1997; Cockburn, 2001; Pal, 2001; Duraisamy, 2000; Tietjen, 1998). Indirect costs include loss of unpaid farm labour and household chores when children go to school. For example, Tietjen (1998) indicated that in rural Ethiopia, girls not in school work on average 14-16 hours a day, mainly engaged in household tasks such as fetching water, boiling coffee, preparing meals, winnowing and transporting grains, while boys are engaged in activities such as ploughing, herding cattle, cutting grass and feeding cattle. Therefore, much of the housework (for girls) and farm work (for boys) will be lost if they are sent to school (Befekadu et al., 2002).

The direct costs include clothing (the social expectation, according to Tietjen, for children attending school is to have higher quality clothing), book rentals and school fees. In relation to these direct costs, Mulat (1997) and Duraisamy (2000) indicated that parents in rural areas are very sensitive to small charges for schooling which results in a more than proportionate school drop-out rate.

Education can also be seen as a consumer good (i.e., valued for its own sake) and as an investment good (being one component of human capital) that will provide future financial returns. In this vein, Tietjen's (1998) findings show that parents believe child schooling results in the betterment of children's lives - and indirectly their own lives through the skills and knowledge children accumulate, and better chance of higher earning capacity. Therefore, economic considerations will influence the parents' decision regarding their children's enrolment (for example, Mulat, 1997; Tietjen, 1998; Duraisamy, 2000; Cockburn, 2001). Based on a sample of rural Ethiopian communities, Tietjen (1998) found that parents' primary reason for educating children was "to secure skills that would lead to employment or opportunities for a good job" - 
a job that not only improves the livelihood of the child but also assists the parents (or the family) economically. Most of the parents interviewed thought their children's education would serve as security in their old age. In light of this, parents overwhelmingly favour boys' education, for the reason that the return on investment in their sons' education is more tangible because the son remains at home when he marries, while a daughter moves far away, implying that the investment in her education cannot be retained by her parents. In a nutshell, authors of this school of thought argue that parents consider the net benefit they gain from children's enrolment by looking at the trade-offs between earning income in the future and losing income now. For this reason the quality of education is very important.

However, for very poor countries we also need to consider the so-called poverty hypothesis. While wealthy households can afford to send their children to school since they can buy clothes, pay school fees, and feed their children, if people are poor they might simply be unable to afford to send their children to school. Shapiro and Tambashe (2001) found that increased economic wellbeing translates into greater investment in children's education for both females and males in Kinshasa, Congo. However, this poverty hypothesis may only work in poor areas or rural areas where income is the most limiting factor for decisions. In a multi-country comparison, Ersado (2003) found a discrepancy between urban and rural areas in the poverty hypothesis of child schooling, finding that while poverty drives schooling decisions in rural areas it does not appear to significantly influence schooling in urban areas.

In this context, child labour is a key concern. Many studies worldwide indicate that child labour, as a factor that reduces child schooling, emerges from the poorest households (Basu and Van, 1998). However, other studies have shown that children of land-rich/ livestock-rich people are more likely to be working, instead of being in school, than children of land-poor/livestock-poor households, indicating that asset ownership and child schooling could be negatively or positively related, depending on the household's economic circumstances. This phenomenon is called the wealth paradox (Bhalotra and Heady, 2003). The reason for the wealth paradox has been investigated in several studies. Ranjan $(1999,2001)$, Jafarey and Lahiri (2002), for example, showed theoretically that credit market imperfections could result in child labour and low enrolment of children in school. Labour market imperfections could also promote child labour and its negative impact on child schooling (Bhalotra and Heady, 2003).

Ownership of production assets such as land and livestock can also affect child schooling in various ways. It can have a positive effect on schooling because larger asset holding may allow households to forgo the income that child work brings. However, in the absence of a perfect labour market, land and livestock ownership can 
also have the opposite effect on child schooling and child labour. Owners of land and livestock who are able to hire productive labour may have an incentive to employ their children instead of sending them to school. Similarly, if households do not have access to credit or if they cannot use their assets as collateral to access credit to employ labour, they are more likely to use their children's labour instead. In the Ethiopian context, Cockburn (2001) found that while land quality increases the relative probability of children's enrolment, ownership of small livestock reduces the probability of school attendance among younger boys. This is because child labour is traditionally more important for cattle rearing than for crop production activities. It could also be because cattle farmers are credit constrained and hired labour cannot be used as a substitute for family (child) labour. In the same vein, distance to the nearest source of water reduces school attendance among girls (see Cockburn 2001: 18-30 for details), presumably because it is largely girls who traditionally fetch water for the household.

In sum, we have to consider the both the income effect (income contribution of the asset itself) and the productivity effect (if access to the asset raises the returns from child work). The income effect tends to increase child enrolment (and reduce child work) while the productivity effect tends to reduce child enrolment (and increase child labour). This relationship, however, may be disrupted by economic shocks such as crop failures, drought and illness, which can act against parental willingness to enrol and keep children in school (Tietjen, 1998). In such cases, children are often required to work and supplement the household income and shortfalls in production. If food shortages (resulting from the shocks) become acute, children might be forced to migrate with parents in search of work and food (Tietjen, 1998), leading to discontinuity of schooling or unwillingness to enrol children at all.

\section{Accessibility of schools}

The demand for education is also likely to be influenced by the distance between the household and the school, as those living farther away from primary school may face higher opportunity (time) and direct (transport) costs. A number of studies have found that the distance to primary school negatively affects the demand for school, with a stronger negative impact for rural children and females (World Bank, 1996; (Befekadu et. al., 2002; Mulat, 1997). This problem is aggravated in rural Ethiopia due to the scattered pattern of settlements. Access to secondary schools is also very limited in rural Ethiopia (secondary education is mainly an urban phenomenon) discouraging child enrolment in rural primary schools in the first place (Befekadu et al, 2002). Some studies indicate that girls face an additional problem of security on their way to school, especially in terms of risk of rape and abduction (Tansel, 1997). 


\section{Parental education}

It has been repeatedly demonstrated that a strong predictor of children's education is parents' educational achievement (Tietjen, 2001; Cockburn, 2001; Duraisamy, 2000; Mulat, 1997; and Pal, 2001). For instance, with a sample size of 540 households, Tietjen found in rural Ethiopia that the simple correlation coefficient between parents' combined educational level and household primary enrolment ratio was found to be positive and significant at 1 per cent, but very low in magnitude (0.11). He admits that the correlation coefficient reported in many other studies is 0.3 or higher but the low correlation in his study could be due to the generally limited level of parental education in rural Ethiopia. Duraisamy (2000) from a study in India, Pal (2001) in Peru and Cockburn (2001) in Ethiopia, arrived at similar conclusions. Ersado (2003) found that, in both urban and rural areas in Ethiopia, adults' educational level is an essential factor in education, making a significant contribution to improvement in the likelihood that children stay at school. Furthermore, Duraisamy (2000) and Mulat (1997) reported that mother's education (as compared to father's education) exerts a much stronger effect of increasing children's enrolment. The relatively low correlation between parents' educational status and school enrolment reported by Tietjen, suggests that other factors may be working in the Ethiopian context and warrants further investigation.

\section{Household composition}

Schooling of children can be affected by the size and composition of the family. Rosati and Rossi (2003) found in Pakistan and Nicaragua that an additional child in the household negatively affects the enrolment rate of children in school. In the Ethiopian context, Mulat (1997) argued that having more children within a family increases the probability of enrolment, assuming other factors are held constant, implying that the probability of going to school declines for households with fewer children. This counter-intuitive finding is partly explained by some of the complex associations between family structure and schooling outlined below. Shapiro and Tambashe (2001) found that family structure (as measured by the number of children in the household in different age groups) and a child's relationship to the head of the household also had a significant influence on investment in children's education. Cockburn (2001), using Ethiopian data, found that there are schooling biases in favour of the firstborn child, that is, the likelihood of attending school tends to increase with the presence of younger siblings, suggesting a birth order effect. He also suggested that children of the head of the household are more likely to attend school than boys or girls who are more distant relatives or unrelated to the head of the household. Overall, a number of studies indicate that children are more likely to be enrolled in school in female-headed households than in male-headed households 
(Mulat, 1997; Duraisamy, 2000; Cockburn, 2001), which may be because they believe educating their children is a means of reducing old-age poverty.

\section{The Importance of School Quality}

Schooling is generally associated with earnings, both in the developed in the developing world. Generally this relationship reflects a causal impact of schooling on productivity and therefore on earnings. Most estimates of schooling, however, merely depict it as "quantity" in terms of years of schooling. However, if there are substantial variations in the "quality of schooling", failure to control for it in earnings functions estimates may cause biases in the estimated returns to schooling.

Behrman and Birdshall (1983) raise several questions about the adequacy of the standard approach in understanding the schooling-earnings relation in order to provide a basis for policy. The standard argument is that there are high returns to expanding primary schooling in developing countries. Quality of schooling has not been ignored, but the tradeoff between further expansion and the possibly more efficient use of resources to improve quality has not been emphasised. Using data for Brazil, Behrman and Birdshall estimate a much lower social return to expanding primary years of schooling once quality is taken into account and indicate that "deepening" schooling by increasing quality has a higher social rate of return that "broadening" schooling by increasing quantity. If these results can be generalised for other countries, the conventional wisdom on schooling investments in developing countries may cause substantial over-investment of resources in schooling with the wrong composition of investments being undertaken.

Along the same lines, many studies of the determinants of economic growth rates across countries use a measure of schooling quantity, such as mean secondary school enrolment rates, to proxy for the rate of human capital accumulation. This approach ignores the contribution of schooling quality. Neri (2001) finds that differences in schooling quality across countries are probably more important than differences in schooling quantity in explaining variations in economic growth rates.

To show the impact of school quality on earnings capacity and educational outcomes, two studies analysing the quality of schools for Black children during apartheid in South Africa show that the lack of resource allocation to improve educational inputs (primarily measured through pupil-teacher ratios) negatively impacted enrolment, educational achievement and test scores for numeracy (Case and Deaton, 1999). Additionally, given that during the system Blacks faced extremely limited residential and school choices, and that Black schools' funding and staffing decisions were made rather arbitrarily, the findings show that the quality of schools in a given district had a 
large and significant effect on the rate of return to schooling for Black men from that district (Case and Yogo, 1999).

Card and Krueger (1992) use a composite index -the pupil/teacher ratio, average term length, and relative teacher pay- to estimate the effects of school quality on the rate of return to education for men born between 1920 and 1949 in the United States. Using earnings data from the 1980 census, the authors find that men who were educated in states with higher-quality schools had a higher return to additional years of schooling. Rates of return were also higher for individuals from states with bettereducated teachers and with a higher fraction of female teachers. Similarly, Lee and Barro (1997), find hat that more school resources -especially smaller class sizes, higher teacher salaries and greater school length- enhance educational outcomes.

\section{Methods}

\subsection{The study population}

This paper uses data from a 2002 survey of eight-year-old children in the Young Lives study of childhood poverty in Ethiopia. This is part of a larger international study involving Ethiopia and Peru, Vietnam and India. In Ethiopia, the survey of eight-yearolds covers 1,001 children aged 7.5 to 8.5 years (mean age 8 years) of whom 51 per cent are males and 48 per cent females.

The data was collected from 20 sentinel sites in five regions, namely, Addis Ababa, Oromia, SNNP, Amhara and Tigray. These regions were chosen partly for logistic reasons (very remote or inaccessible areas being excluded) but also because they contain the majority of the Ethiopian population (96 per cent). Within regions, sentinel sites targeted poor areas based on the government's food insecurity designation. Three out of four sentinel sites in each region are in high food deficit woredas (districts) and one is from a lower food deficit woreda. Consequently, the sentinel sites over-sampled the poor but included a degree of variation for comparative purposes. The sentinel sites were distributed over the five regions in such a way that Amhara, Oromia and Tigray had 20 per cent of the sample each while SNNP had 25 per cent and Addis Ababa 15 per cent. Forty per cent of the children were from urban areas and the remaining 60 per cent from rural areas.

\subsection{Analysis}

Both descriptive and multivariate analyses were used to explore the correlations between children's enrolment in school and household wealth index, parents' education, social capital, economic shocks and ownership of land, among other factors. Data were initially captured using a Microsoft Access database and analysis 
conducted using Stata version 8 and SPSS 12.0. The descriptive method of analysis includes cross tabulation between pairs of variables (the probability of a child being enrolled in primary school and its potential determinants) and conducting Pearson's chi-squared test $\left(\chi^{2}\right)$ to test the null hypothesis that the pairs of variables are independent of each other. The multivariate analysis used a probit model to examine factors influencing whether a child is enrolled in primary school or not.

\section{Results}

\subsection{Descriptive statistics}

Descriptive statistics of the relevant variables for this study are presented in Tables 4.1 and $4.2 .^{11}$ The highest educational grade completed by the eight-year-old children was four. Although many of the children had not been in school long enough to complete any grades (33 per cent), a significant number had already completed grade one (21 per cent) and two (9.6 per cent), with a few having completed grade three or four (2.3 per cent). This result was consistent with the 28 per cent who reported children starting school before the child was seven years old (the official school entry age). About 3 per cent of the eight-year-old children worked for money or goods, according to their caregivers instead of attending school.

\section{Table 5: Descriptive statistics of dichotomous variables}

\begin{tabular}{lc}
\hline & Percent \\
\hline Male children & 51 \\
From Amhara & 20 \\
From Oromia & 20 \\
From SNNP & 25 \\
From Tigray & 20 \\
From Addis Ababa & 15 \\
From urban areas & 40 \\
Children involved in paid work (caregiver's response) & 4 \\
Children involved in paid work (child's response ) & 9 \\
Households in the sample whose welfare has decreased due to & 78 \\
considerable economic change(s) in the last three years & 41 \\
Households in the sample who own or rent land & 76 \\
Male heads of household & 70 \\
Households in the sample who own livestock & 67 \\
Children involved in household chores (caregiver's response) &
\end{tabular}

Number of observations is 1,000 .

\footnotetext{
${ }^{11}$ For full details of the household and child characteristics see the Young Lives Preliminary Country Report for Ethiopia (Alemu et al, 2003) or www.younglives.org.
} 
Table 6: Descriptive statistics of continuous variables

\begin{tabular}{|c|c|c|c|c|}
\hline & Minimum & Maximum & Mean & SD \\
\hline Highest grade completed by child & 0 & 4 & 0.48 & 0.77 \\
\hline Household size & 2 & 16 & 6.42 & 2.16 \\
\hline Years of schooling of mother & 0 & 13 & 2.05 & 1.07 \\
\hline Years of schooling of father & 0 & 16 & 2.83 & 4.02 \\
\hline Wealth index* & 0.01 & 0.77 & 0.17 & 0.16 \\
\hline $\begin{array}{l}\text { Social support (number of individuals and groups from which } \\
\text { the caregiver receives any kind of support)* }\end{array}$ & 0 & 12 & 2.42 & 2.64 \\
\hline Average number of bad events over the last three years* & 0 & 11 & 2.33 & 1.94 \\
\hline $\begin{array}{l}\text { Cognitive social capital (caregiver's perceptions of the local } \\
\text { community)* }\end{array}$ & 0 & 4 & 3.49 & 0.79 \\
\hline $\begin{array}{l}\text { Absolute structural social capital (based on the number of } \\
\text { groups caregiver is a member of)* }\end{array}$ & 0 & 7 & 1.60 & 1.21 \\
\hline $\begin{array}{l}\text { Citizenship (based on whether or not the caregiver has worked } \\
\text { with others in the community to address a common issue)* }\end{array}$ & 0 & 2 & 0.80 & 0.84 \\
\hline Hours the child works on household chores & 1 & 12 & 1.54 & 1.99 \\
\hline Mean distance from community to primary school (in km) & 2.52 & 0.50 & 9.17 & 2.87 \\
\hline
\end{tabular}

Number of observations is 1,000. * For definitions of wealth index, social capital and economic shocks see the Young Lives Preliminary Country Report (Alemu et al, 2003). See also Tables A8 and $\mathrm{A} 9$ in the appendix for the definition wealth index and social capital, respectively).

\subsection{Univariate analysis of factors related to children's enrolment in school}

This sub-section presents results of cross tabulations of whether the child was currently enrolled in school against those variables that are expected to be correlated with enrolment, based on the literature. The summary of cross tabulation analysis is presented in Tables 4.3 and 4.4. The following variables have a statistically significant association with school enrolment of eight-year-old children (at the 1 per cent level or less): location (urban/rural), poverty status (wealth index), years of mother's schooling, ownership of land, absolute household size, paid and unpaid child labour, number of economic shocks, and absolute structural social capital. Contrary to what is reported in the findings of other studies, female-headed households were slightly less likely to enrol their child in school but this was not significant at the 5 per cent level $(p=0.066)$. Cognitive social capital and citizenship were not statistically correlated with enrolment of the child. The distance to primary schools had a significant negative relationship with enrolment. In our sample, there was a small difference between enrolment rates for boys and girls but this was not statistically significant (Table 7). 
Table 7: Pearson's chi-square test for the determinants of child enrolment in school

\begin{tabular}{|c|c|c|c|c|}
\hline Variable & $\begin{array}{l}\text { Sign of } \\
\text { relationship }\end{array}$ & $\begin{array}{c}\text { Pearson's } \\
\chi^{2} \text { test } \\
\text { statistics }\end{array}$ & $\begin{array}{c}\text { Degrees } \\
\text { of } \\
\text { freedom }\end{array}$ & $\begin{array}{l}\text { Prob }>\chi^{2} \\
\text { (P-Value) }\end{array}$ \\
\hline Location ( 1 if urban and 0 if rural) & $(+)$ & 7.61 & 1 & $0.000^{* * *}$ \\
\hline Wealth index (three categories) & $(+)$ & 147.03 & 2 & $0.000 * * *$ \\
\hline Years of mother's schooling & $(+)$ & 56.8 & 14 & $0.000 * * *$ \\
\hline Years of father's schooling & $(+)$ & 31.9 & 15 & $0.007^{* * *}$ \\
\hline Cognitive social capital & $(+)$ & 1.76 & 4 & 0.780 \\
\hline Citizenship & $(+)$ & 0.19 & 2 & 0.912 \\
\hline Ownership of land & $(-)$ & 76.82 & 1 & $0.000^{\star * *}$ \\
\hline Ownership of livestock & $(-)$ & 29.30 & 1 & $0.000^{\star * *}$ \\
\hline Household size & $(-)$ & 22.00 & 12 & $0.000^{\star \star *}$ \\
\hline $\begin{array}{l}\text { Did the child do paid work? (caregiver's } \\
\text { response) }\end{array}$ & $(-)$ & 15.52 & & $0.000^{\star \star *}$ \\
\hline $\begin{array}{l}\text { Hours child spends on household chores } \\
\text { (caregiver's response) }\end{array}$ & $(-)$ & 51.73 & 12 & $0.000^{\star * *}$ \\
\hline Number of economic shocks & $(-)$ & 62.65 & 9 & $0.000^{\star * *}$ \\
\hline Absolute structural social capital & $(-)$ & 27.41 & 7 & $0.000 * * *$ \\
\hline Social support received & $(-)$ & 21.69 & 12 & $0.041^{* \star}$ \\
\hline Sex of head of household ( 1 if female) & $(-)$ & 3.30 & 1 & $0.066^{\star}$ \\
\hline Cognitive social capital & $(+)$ & 1.76 & 4 & 0.780 \\
\hline Citizenship & $(+)$ & 0.19 & 2 & 0.912 \\
\hline Sex of child (1 if male) & $(-)$ & 1.65 & 1 & 0.194 \\
\hline Did the child do paid work? (child's response) & $(-)$ & 0.57 & 1 & 0.452 \\
\hline Region & & 60.14 & 4 & 0.000 *** \\
\hline
\end{tabular}

* Significant at 10\%; ** significant at 5\%; ${ }^{* * *}$ significant at $1 \%$; P-value is the lowest significance level at which the null hypothesis is rejected.

Table 8: Children enrolled in school by sex of child

\begin{tabular}{ccc}
\hline Sex & Not in school & In school \\
\hline Female & 31.22 & 68.78 \\
Male & 35.10 & 64.90 \\
\hline
\end{tabular}

Pearson $\chi^{2}(1)=1.6907 \mathrm{p}=0.194$

The validity of the identified relationships is limited, based on simple cross tabulations, since there is no control over the effects of other associated (confounding) factors. Multivariate techniques were used to control for potential confounders and produce a more complete picture.

\subsection{Multivariate analysis of factors related to children's enrolment in school}

To assess the determinants of a child being sent to school, two versions of a probit model were estimated. Guided by the literature and the results of the univariate analysis, these models were used to test the hypothesis that human capital, including 
parent's education, financial capital, including economic shocks and child labour ${ }^{12}$, physical capital, measured by access to schools (proxied by distance), and social capital, are correlated with a child's likelihood of enrolment ${ }^{13}$. Confounding factors such as the sex of the child and the head of the household, region, and household size (disaggregated by age) were included as explanatory variables. The detailed results of the estimations are presented in Tables A1 to A5, in Appendix A. ${ }^{14}$

Results from the probit model of a child being in school (a dichotomous variable with a value 1 when a child is in school and 0 if she/he is not) are extracted and presented in Table 9.

Table 9: Determinants of a child being in school (estimated using a probit model)

\begin{tabular}{|c|c|c|}
\hline Explanatory variables & Marginal effect & Quasi-elasticity $^{+}$ \\
\hline Dummy for male child & $\begin{array}{l}-0.035 \\
(1.16)\end{array}$ & -0.018 \\
\hline Dummy for Amhara Region & $\begin{array}{r}0.146^{\star \star \star} \\
(3.58)\end{array}$ & 0.029 \\
\hline Dummy for SNNP Region & $\begin{array}{r}-0.078^{*} \\
(1.79)\end{array}$ & -0.019 \\
\hline Dummy for urban residence & $\begin{array}{l}0.123^{*} \\
(1.94)\end{array}$ & 0.049 \\
\hline Wealth index consumer durable & $\begin{array}{r}1.075^{\star \star \star} \\
(5.07)\end{array}$ & 0.188 \\
\hline $\mathrm{HH}$ Size $\mathrm{b} / \mathrm{n}$ the age of 5 and 15 & $\begin{array}{r}-0.026^{*} \\
(1.82)\end{array}$ & -0.042 \\
\hline $\mathrm{HH}$ Size above the age of 15 & $\begin{array}{r}-0.030^{\star *} \\
(2.40)\end{array}$ & -0.087 \\
\hline Maximum Grades completed by Male members of a $\mathrm{HH}$ & $\begin{array}{r}0.012^{\star *} \\
(2.48)\end{array}$ & 0.061 \\
\hline Maximum Grades completed by Female members of a $\mathrm{HH}$ & $\begin{array}{r}0.017^{\star \star \star} \\
(3.13)\end{array}$ & 0.073 \\
\hline
\end{tabular}

\footnotetext{
${ }^{12}$ Child labour is potentially an endogenous variable. It could jointly determine with whether or not a child goes to school. This type of endogeneity problem required instrumental variables estimation method. However, given the cross sectional nature of the data, it has been very difficult to find good instruments to correct for the endogeneity of child labour.

${ }_{13}$ Please note that we recognize that a livelihoods framework does not fully capture the complexities for child enrolment, especially with regard to child labor and accessibility of schools.

${ }_{14}$ We used the following order of estimation in the probit model. First a model with all explanatory variables is estimated. Then we conducted a likelihood ratio test to see if the coefficients of some the variables whose $t$-values are less than one are jointly zero. The null hypothesis that the coefficients are jointly zero cannot be rejected. Hence we run a restricted model with variables whose t-values are greater than or equal to 1 in the first model. A test for multicollinearity was conducted. We did not find serious problem of multicollinearity (see Appendix 1). Belsley, Kuh and Welsch (1980) suggest that condition number in excess of a value 20 is indicative of multicollinearity; and according to Gujarati (1995) we should not worry about multicollinearity if the mean variable inflation factor is less than two. To account for heteroscedasticity, we use robust estimation method in which the standard errors are corrected for heteroscedasticty of unknown form. Our interpretation of the result is based on the restricted model.
} 


\begin{tabular}{|c|c|c|}
\hline Number of events that decreases the $\mathrm{HH}$ welfare & $\begin{array}{r}-0.020^{\star \star} \\
(2.49)\end{array}$ & -0.048 \\
\hline Cognitive Social Capital & $\begin{array}{r}0.046^{\star *} \\
(2.38)\end{array}$ & 0.160 \\
\hline Absolute structural social capital & $\begin{array}{r}-0.029^{\star *} \\
(2.19)\end{array}$ & -0.046 \\
\hline Dummy for $\mathrm{HH}$ owns or rent land & $\begin{array}{r}0.175^{\star \star \star} \\
(3.12)\end{array}$ & 0.104 \\
\hline Dummy for the Ownership of livestock & $\begin{array}{r}-0.072^{*} \\
(1.83)\end{array}$ & -0.051 \\
\hline Dummy for a child being involved in paid work & $\begin{array}{r}-0.113^{\star \star} \\
(2.11)\end{array}$ & -0.010 \\
\hline Number of hours a child spent on $\mathrm{HH}$ chores & $\begin{array}{r}-0.015^{\star *} \\
(1.97)\end{array}$ & -0.023 \\
\hline Mean distance (KM) to public and private primary schools1 & $\begin{array}{r}-0.018^{\star \star \star} \\
(2.61)\end{array}$ & -0.046 \\
\hline
\end{tabular}

Robust $t$ statistics in parentheses; * significant at 10\%; ** significant at $5 \%$; ${ }^{* * *}$ significant at $1 \%$

See Tables A1 and A2 for details of the estimated results; ${ }^{+}$Quasi-elasticity measures a change in the probability of a child being enrolled in primary school when a given explanatory variable change by one percent.

\section{Human capital}

Parents' education is potentially an important determinant of child school attendance since it is assumed that educated parents are more able to recognise the long-term benefits of education and thereby try to help their children to have a better education. Equally importantly, educated parents may derive more satisfaction from educated children than illiterate parents.

The gender of the parent may also play an important role. Al-Samarrai and Peasgood, 1998, for example, argue that in the Tanzanian context mothers may have stronger preference than fathers for sending their children to school, and in particular on the enrolment of girls (Glick and Sahn, 2000). As their own education increases, mothers' bargaining power within the household to follow through on these preferences also improves (Al-Samarrai and Peasgood, 1998).

To explore these issues, the highest school grade completed by male and female members of a household and the highest grade completed by the mother and father were used as explanatory variables in a probit regression model (see details in Appendix A, Table A1 and A2). Controlling for other factors, we found that both the maximum level of education of male and female members of a household have a statistically significant, positive effect on the probability of a child being in school. 
When we ran separate regressions for male and female children, we found that mother's education had a positive, but not statistically significant effect on the enrolment of male children only, while the effect of father's education was not significant for either sex. The same result was observed regarding the effect of the maximum level of education of female and male household members, with the aggregate educational level of female members having a positive and insignificant effect on the school enrolment of male children.

In terms of urban/ rural differences, we found that the influence of a mother's education had a positive and statistically significant effect on the probability of a child being in school only in urban areas. However, the effect of the maximum educational level of male and female members on child school enrolment was statistically insignificant in both rural and urban areas.

There were marked regional differences in the impact of maximum schooling of male and female members on the probability of a child being in school. The maximum education level of female members had a significant positive effect in all regions except in Amhara while only in Tigray Region did the maximum education level of male members showed a significant positive effect on child school enrolment.

Household composition, disaggregated by sex, did not show any significant effects on enrolment. However, household composition disaggregated by age had a differential impact on child enrolment. The greater the number of children in the household between the ages of 5 and 15 and the greater the number of household members above 15 years old had a negative and significant effect on child enrolment. This result suggests that parents who have many school-age children cannot afford to send them all to school because more young children means more competition for resources. Our finding about adult members is more puzzling: in theory one would expect that more adult members would result in greater income and remittances to pay for school costs but this was not the case in our sentinel sites. One possible explanation for this puzzling result could that the adult members are not generating enough income to help children because of lack of employment opportunities and small farm size.

The effect of birth order (which is highly correlated with household size with an order of 0.72 correlation coefficient) was also found to be statistically significant and negatively correlated with the probability of a child being enrolled, indicating the chance of a child being sent to school is less when there are more children/members above the age of the index child. 


\section{Financial capital}

We found that the wealth of a household (as measured by the Young Lives wealth index $)^{15}$ had a positive and statistically significant association with the probability of a child being enrolled in primary school. The ownership of land, which is not included in our wealth index, also had a positive effect on the probability of a child being sent to school, reinforcing the conclusion that wealth, or at least a lower level of absolute poverty, is an important factor for increasing child school enrolment. However, ownership of livestock was found to be negatively associated with child enrolment, probably because children's labour ${ }^{16}$ is normally used for herding cattle. This result lends support to the idea of the wealth paradox observed in Pakistan and Ghana (Bhalotra and Heady, 2003). That is, if households cannot get credit and hire labour, or if hired labour cannot be a substitute for family labour, the ownership of a livestock asset can result in increased demand for child labour. Given that many people do not have access to credit in Ethiopia (Woldehanna, 2000), it is not surprising to see such a paradox demonstrated here.

The effect of wealth on child enrolment in school is positive and significant for both male and female children, but only in rural areas. Wealth as measured by consumer durables (proxied by the Young Lives wealth index) is not the main determinant of child enrolment in urban areas (similar to the result observed by Ersado, 2002). The regional difference in the wealth effect on child enrolment is worth noting. Wealth has a significant and positive effect on child enrolment in Amhara, Oromia, Tigray, and SNNP, but not in Addis Ababa, where access to public schooling is largely not determined by wealth because public schools are not far from many of the residences' home.

The probability of a child being enrolled is negatively related to their being involved in paid farm and non-farm work and in household chores. The effects are statistically significant for both paid work and household chores. The effect of livestock ownership on child enrolment in school is negative in Amhara region indicating that children in Amhara are less likely to go to school because they are involved in livestock herding. Although requiring further research, this is possibly because there are more livestock per household but restricted access to grazing and thus children are required to follow the cattle. In Addis Ababa, the probability of children's enrolment declines when children are more involved in household chores.

\footnotetext{
${ }^{15}$ See Alemu et al., 2003.

${ }^{16}$ While child labour should strictly be regarded as an element of human or social capital in this context, its use is so intimately related to wealth that it is discussed here.
} 
The effect of unpaid child labour (household chores) on school enrolment is negative and statistically significant for male children only, while the effect of livestock ownership is negative and statistically significant on female children only. This result seems surprising given the fact that female children are more involved household chores than male children and male children are more involved in livestock herding than female children in Ethiopia. More research is clearly needed to unpack this seeming paradox.

The involvement of children in paid work and household chores has a more significant negative effect in rural areas than in urban areas. Children's labour is in greater demand in rural areas for farm work, off-farm work (i.e. farm-related but not on family-owned land) livestock herding and household chores, and linked to the time-consuming nature of fuel wood collection, fetching water, food preparation and farm work in rural areas, which increases the demand for children to do household chores.

The more shocks a household faces, the lower the probability that the household sends their child to school. This result is statistically highly significant. The effect is more pronounced for rural areas and in the case of male children. This is perhaps because male children are more likely to be required to generate income during economic shocks than female children and shocks are more prevalent in rural areas than in urban areas. Of all the regions, the effect of economic shocks on children's enrolment is most pronounced in Tigray where there is a relatively more frequent drought.

\section{Physical capital}

For children not attending school, along with the burden of education-related costs and the need for children's labour to supplement the household economy, distance was found to be one of the most common explanatory factors. In the multivariate analysis the greater the distance from the household, the lower the probability that parents send their children to primary school. This effect is more pronounced and statistically significant for girls and rural areas. Anecdotal evidence indicates that there is greater concern for girls' safety while travelling to and from school since they are vulnerable to physical and sexual violence. In urban areas distance to schools was not found to be a determining factor for children's enrolment. 


\section{Social capital}

There has been relatively little discussion in the literature about the impact of social capital on education and educational outcomes. We hypothesise that social capital (i.e., the formal and informal relationships among individuals and communities and the relationship of trust and tolerance involved) may help to improve child schooling in two possible ways. First, it may involve the communication of information and the raising of awareness about the importance of child schooling. When a market is constrained by information flow between economic agents, social capital may help in facilitating communication between them. Civil associations and networks of interpersonal social relations facilitate information flows and thereby help to reduce information asymmetries. In doing so, social capital could help to solve the problem of limited communication. Second, social capital might have a complementary effect on government efforts to build schools and encourage enrolment. More specifically, in communities with stronger social capital we could hypothesise that communities might pressure local, regional and national government to invest more resources in schools and schooling.

Cognitive social capital (reflecting caregiver's perception of the local community in terms of trust, self-esteem, 'belongingness', perception of people's co-operation and being used by others) has a positive and significant effect on the probability of a child being enrolled. In contrast, absolute structural social capital (as defined by citizens' participation in community groups) had a negative and significant influence on child enrolment. This result might not be surprising, as the most frequent form of structural social capital in our sample was membership in religious groups, which given their conservative tendencies in the Ethiopian context, could be related to resistance to modern education (see further discussion in Section 5). Citizenship (defined as 'whether or not the caregiver has worked with others in the community to address a common issue' (Alemu et al. (2003)) and social support (defined as 'whether or not the caregiver received support in the year before the survey period (2002)' Alemu et al. (2003)) were found to be positively associated with child enrolment, but none of these variables was statistically significant at the 5 or 10 per cent level.

\section{Interaction effects}

According to livelihoods theory, ownership of household assets of various kinds may reduce their overall vulnerability to natural and human-made disasters (DFID, 1999; Lockwood, 2001). To test this hypothesis, we used the interaction of asset variables (such as cognitive social capital, absolute structural social capital, ownership of livestock and land) with a variable for shocks in our regression analysis. However, 
none of these interacting variables had a statistically significant correlation with child school enrolment, perhaps because the social capital people own are traditional that they do not contribute much to acquire economic assets (livestock) and to reducing vulnerability to area-wide shocks.

\subsection{Relative magnitude of the impacts}

The relative importance of variables is assessed using quasi-elasticity estimates as shown in the last column of Table 9. The most important factors for child enrolment were wealth, cognitive social capital, ownership of land, adult household size, females' education, males' education, and ownership of livestock. This result is contrary to a previous study that indicated that adult education has weak correlation with child schooling (Tietjen, 2001). Maximum education of male adult education has less effect than that of the female members in terms of both magnitude and statistical significance. Table A3 also indicated that Mother's education has stronger effect than father's education on child enrolment in primary schooling although none of them are statistically significant. Among the social capital variables, cognitive social capital has the strongest effect on child schooling.

\section{Summary of results and policy implications}

\subsection{Summary of Results}

The paper has examined the external factors that impact on school enrolment by poor children. ${ }^{17}$ The multivariate analysis robustly indicated that wealth / levels of asset holding, cognitive social capital, the level of adult female education and ownership of land had a positive impact on whether eight-year-old children were enrolled at school. In terms of the relative impact of these variables, the household's wealth level was the most important factor, followed by cognitive social capital (levels of trust and reciprocity) the maximum level of education attained by female adults in the household, ownership or rental of land, and the maximum level of education attained by male adults in the household, in declining magnitude. By contrast, child enrolment was found to be negatively associated with the following variables, in declining magnitude: the number of household members over the age of 15 years, ownership of livestock, the number of events/shocks that decreased household welfare, the mean distance to primary schools, absolute structural social capital (i.e. the number of community groups in which the caregiver is a member), the number of children

\footnotetext{
${ }^{17}$ As with all cross-sectional studies, causality cannot be attributed to the associations found in this paper. In addition, the over sampling of poor respondents for the Young Lives study means that these results can not be generalized to the population of Ethiopia as a whole but are indicative of the situation of poor children.
} 
aged between 5 and 15 years in the household, the number of hours per day the child spends on household chores and whether or not the child is involved in paid work.

\subsubsection{Implications for Education Policy}

Our findings suggest that increasing child enrolment in school - a key policy goal of the SDPRP and the ESDP - will necessitate more targeted educational policies, especially in order to address significant disparities between boys and girls and among children in different regions of Ethiopia.

First, because distance is one of the major factors that affect enrolment, especially for rural children and girls, policy initiatives are needed that improve the proximity of schools in remote parts of the country and simultaneously address safety issues for girl children. While the most obvious policy option is to build more schools and develop a standard for equitable distribution of schools in a region or a wereda on the basis of acceptable distance (considering the topographic constraints) children could travel to schoo ${ }^{18}$, cost constraints represent a significant obstacle. That is, while the program cost for ESDP II is 15.1 billion Birr, the actual budget fixed for the program was only 11.5 billion Birr, and the budget shortfall was expected to be covered by reducing unit costs (MoE 2002). Another more realistic option is to develop lower-cost alternative education programs in under-provisioned areas, which following the successful pilots by NGOs in several regions of the country are now being rolled out by the Ministry of Education.

Indeed such alternative education programs not only address educational infrastructural shortcomings, but also help to address another issue that arose from our findings, namely that of finding a balance between the demands for children's labor (paid or unpaid) and school enrolment. Yet while the ESDP and SDPRP recognized non-formal education programs as a policy priority, budget commitments remain low (MoE, 2002). The exceptions are the Amhara and Oromia regions where such programs have been introduced with reasonable coverage (personal communication with the head of Amhara Region Bureau of Education) ${ }^{19}$. If the government is to achieve the educational Millennium Development Goal of universal

\footnotetext{
${ }^{18}$ For example, the 2002 Health Sector Development Program mandates that there should be a health clinic in a $10 \mathrm{~km}$ radius of every village.

${ }^{19}$ NGOs such as Save the Children UK, the Save the Children Alliance members (Sweden, Norway, Denmark and USA), Action Aid and others have piloted Alternative Basic Education (ABE) in different parts of the country and have tried to influence regional governments to institutionalise it. It is cheaper to expand non-formal education than the formal First Cycle schools and, being more flexible, ABE may be better able to accommodate children's needs in poor communities. Currently concerned NGOs and the Ministry of Education are working to ensure that these ABE programs integrate with the formal system so a child could continue in the formal system after attending an ABE.
} 
primary education by 2015 , it should consider expansion of ABEs to all the regions, wereda, and communities, with special emphasis on marginalised areas.

Given the strong positive association between female adult education and child enrolment, girls' education clearly has multi-purpose effects and investing in girls' education today at all costs (apart from education being a right on its own) is an investment in ensuring educated future mothers. In addition, our findings underscore the importance of (re)introducing adult literacy programs, especially for women. While the government has a number of adult and non-formal education programmesprogrammes for out-of-school children aged 7-14, literacy programmes for young people and adults over the age of 15 , and basic skills training for young people and adults-there are no specific programmes targeting female adult education. The dearth of such programmes needs to be addressed, given the strong positive association found here between adult female education and child enrolment. The case for investing in formal female education is further strengthened by the positive association between maternal education and child health and nutritional wellbeing (Christiaensen and Alderman, 2004).

However, while female adult education has a generally positive impact on child schooling, we found a more significant impact on boys' than girls' schooling. As discussed earlier there are several possible reasons: in the short term, girls are needed to help with household chores and childcare work, and thus mothers are likely to be less supportive of education for girls as they depend on daughters' unpaid labour. In the longer term, investing in boys' education will reap direct benefits when they reach adulthood and are expected to support the family through paid employment. Daughters by contrast marry into another family and the fruits of their labours benefit another family. This suggests then that it is not sufficient to simply rely on the argument that more educated mothers leads to greater school enrolment, but given the differential gender impact, focused government policy initiatives to boost girls' enrolment and attendance are called for. While there is an expressed commitment on the part of the government in the Education and Training Policy, SDPRP, Population Policy and Social Welfare Policy, to enhance girls' education in the country, a collaborative and inter-sectoral approach needs to be developed in order to give the urgent issue of improving girls' education the importance it deserves. Possible measures could include advocacy campaigns to encourage greater sharing of household tasks among all family members; the introduction of technology to save burdensome household tasks; the enforcement of the Family Law (which prohibits early marriage i.e. under 18 years of age); and empowerment programs for women (including adult literacy classes), which could potentially have a spill-over impact on the aggregate wealth of the household and children's educational attainment. 


\subsubsection{Implications for Inter-sectoral Policy}

Given that our findings demonstrated that child enrolment is shaped by a number of external household livelihoods and community variables, achieving universal primary education for all is clearly also going to necessitate broader inter-sectoral policy initiatives. This section therefore discusses the economic and social policy implications of our findings.

Not surprisingly, we found that children from wealthier households (using household durable assets as a proxy for income) have a better chance of going to school than children from asset-poor households. We may therefore assume that policies geared towards wealth creation opportunities for poor households should raise the chances of child enrolment. Yet because children in poor households play a major role in augmenting household income, the returns from child work will also need to be substituted from another source such as increased parental income. Therefore policies directed towards increasing the income and assets of poor households should consider the impact that it will have on human development in terms of child schooling.

One of the central pillars of the Ethiopian PRSP, however, is the so-called Agricultural Development-Led Industrialisation Strategy, which being based on labour-intensive agricultural activity, is likely to increase the demand for child labour (MoFED, 2002b). Premised on the argument that in a capital-deficit country, such as Ethiopia, the alternative route to growth is the use of abundantly available labour (MOI, 2002), ADLI overlooks the role of children in the household economy. That is, adding extra activities to the household without a change in technology or the capacity to use hired adult labour increases the likelihood of children's greater involvement in agriculture and/or household reproductive responsibilities (such as childcare or domestic work) to compensate for the involvement of women or older siblings in non-domestic labour at the expense of their right to education and the future of the country ${ }^{20}$ (ILO Convention 138).

Several specific policy initiatives could help mitigate these problems. First, the introduction of more time-efficient methods of keeping animals would help reduce the time children spend in tending livestock. There are a number of possibilities including:

\footnotetext{
${ }^{20}$ The effect on girls would be stronger if mothers are engaged in a day-long income generating activities away from the home because girls have to take over their mothers' domestic role at home: providing care for younger children, fetching water, cleaning the house, cooking meals, etc. In these circumstances girls would lose their chance of going to school or be withdrawn, if they were in school, because they have to replace their mothers to care for younger siblings.
} 
- preparing sufficiently sizeable package of forage packages so as to reduce children's daily burden of taking animals to grazing areas;

- developing a shift system so children can balance school and work;

- reducing the number of cattle kept by households and encouraging a shift in focus from quantity to quality as is the case in the Harari region.

- providing enclosures for common grazing land where either pooled community labour (as is this case in Guraghe in the south of Ethiopia) or hired adult labour could be used to keep animals from different households and thereby release children to go to school. Such a strategy could be integrated within the agricultural extension system.

The ADLI strategy also envisages growth in household income will lead to improved standards of living and in turn rising demand for social services, including education (ibid.). However, without simultaneous investment by parents and the public in children's education (human capital) now, growth will be unsustainable, if not impossible. To ensure long-term benefits for children, a balance has to be created between work and education where working hours are minimised while at the same time maximising opportunities for other activities such as education and leisure. One good example is the recently launched joint donor-government conditional safety net initiative in food insecure areas. This safety net will cover food insecure households, and will involve food or cash transfers on the condition that the children are sent to school.

In addition to such food security measures, given the important negative impact of household economic shocks in our research, we would also underline the importance of developing policies and strategies that build up a household's resilience to events such as crop failure, reduced availability of food or a loss of livestock. Important here will be measures to reduce a household's dependence on rain and a single source of income, creating safety nets to mitigate the effects of shocks and making services (including markets and road infrastructure) accessible.

Lastly, our findings about social capital, suggest that the involvement of the broader community in promoting child education could be potentially important, but still requires further research to fully understand the underlying mechanisms. Our initial hypothesis, however, is that the main local organisations of which most caregivers are members, such as funeral societies, religious groups, and community groups, currently have a negative impact on schooling as they are more likely to reinforce conservative social ties, beliefs and values (see Table A7). In other words, the assumption that absolute structural social capital facilitates information exchange among members has not been supported by our data. Yet, rather than concluding that group membership will not be able to play a positive future role in facilitating 
school enrolment, it could be argued that such groups lack the necessary information and awareness about educational services as they are mutually disadvantaged. The policy implication therefore would be to take advantage of the relatively large membership in religious and traditional community organizations to facilitate information sharing. Initiatives should be promoted to make information accessible to local groups and organisations about the importance of education and the availability of formal and non-formal educational services through community radio, civil society organisations, such as NGOs, and through government consultations, especially wereda administrations. 


\section{References}

Alemu, T., G. Asgedom, J. Liebenberg, A. Mekonnen, J. Seager, B. Tefera and T. Woldehanna 2003. Young Lives Preliminary Country Report: Ethiopia, Young Lives, London

Al-Samarrai, S. and Peasgood, T. 1998. Educational Attainment and Household Characteristics in Tanzania, Economics of Education Review, 17(4): 395-417

Basu, K. and P. H. Van. 1998. The Economics of Child Labor, American Economic Review, 88 (3), 412-27

Befekadu Degefe, Berhanu Nega, and Getahun Tafese. 2002. Annual Report on the Ethiopian Economy, Addis Ababa, United Printers

Behrman, Jere and Birdshall, Nancy. 1983. The Quality of Schooling: Quantity alone is Misleading; The American Economic Review, Vol. 73, No. 5; December, 1983.

Belsley, D, E Kuh and R Welsh. 1980. Regression Diagnostics, New York, John Wiley and Sons

Bhalotra, S and C Heady. 2003. Child Farm Labour: The Wealth Paradox, The World Bank Economic Review, 17:197-227

Camillo, Furio; and Rossi, M. 2003. Children's Working Hours and School Enrollment: Evidence from Pakistan and Nicaragua. The World Bank Economic Review 17(2): 283295.

Card, David and Krueger, Alan. 1992. Does School Quality Matter? Returns to Education and the Characteristics of Public Schools in the United States; Journal of Political Economy, University of Chicago Press, vol. 100(1), pages 1-40.

Case, Anne and Deaton, Angus. 1999. School Inputs and Educational Outcomes in South Africa; The Quarterly Journal of Economics, MIT Press, vol. 114(3), pp 1047-1084.

Case, Anne and Yogo, Motohiro. 1999. Does School Quality Matter? Returns to Education and the Characteristics of Schools in South Africa; NBER Working Papers 7399, National Bureau of Economic Research, Inc.

Christiaensen, L and H Alderman. 2004. Child Malnutrition in Ethiopia: Can Maternal Knowledge Augment the Role of Income? Economic Development and Cultural Change, 52(2): 287-312

Cockburn, J. 2001. Child Labour Versus Education: Poverty Constraint or Income Opportunity? Centre for the Study for African Economies (CSAE), Oxford University, Oxford, UK.

CSA. 2004. Ethiopia Child Labour Survey', Statistical Bulletin 262

Department for International Development (DFID).1999. Sustainable Livelihoods and Poverty Elimination. Background briefing, 9 November, 1999. Retrieved from URL www.livelihoods.org/info/docs/de99bbfg.htm.

Duraisamy, M. 2000. Child Schooling and Child Work in India, Indian Institute of Technology. http://fmwww.bc.edu/RePEc/es2000/0837.pdf

Ersado, L. 2003. Child Labor and School Decisions in Urban and Rural Areas: Cross-country Evidence, IFPRI Discussion Paper 145

Glick, P and Sahn, D. E. 2000. Schooling of Girls and Boys in a West African Country: The Effect of Parental Education, Income and Household Structure, Economics of Education Review, 19(1):63-87 
Greene, W. H. 1997. Econometric Analysis. $4^{\text {th }}$ edition. London: Prentice-Hall International (UK) Limited

Jafarey, S and S Lahiri. 2002. Will Trade Sanctions Reduce Child Labour? The Role of Credit Markets, Journal of Development Economics, Vol. 68, 137-56

Lee, Jong-Wha and Barro, Robert. 1997. Schooling Quality in a Cross Section of Countries, NBER Working Papers 6198, National Bureau of Economic Research, Inc.

Lockwood, M. 2001. Childhood Poverty: A Conceptual Framework and Research Agenda, nonpublished memo

Ministry of Education (MoE). 2002a. Education Sector Development Programme II (ESDP II), Addis Ababa, Ministry of Education

. 2002. Education Sector Development Programme II (ESDP II): Addis Ababa, Ministry of Education.

. 2001. Midterm Review of the Education Sector Programme Phase I, MoE, Addis Ababa

1994. Education and Training Policy, Federal Democratic Republic of Ethiopia, MoE, Addis Ababa.

Ministry of Finance and Economic Development (MoFED). 2002a. Ethiopia: Sustainable Development and Poverty Reduction Strategy, Addis Ababa . Poverty Profile of Ethiopia, March, Addis Ababa, Ethiopia

Ministry of Information (Mol) (2002). Rural Development Policies and Strategies, The Government of Federal Democratic Republic of Ethiopia, Addis Ababa, Ministry of Information

Mulat .1997. Demand for Education and Returns to Investment in Education in Ethiopia. Proceedings of the Seventh Annual Conference on the Ethiopian Economy on Human Resources Development held on 28-30 November 1997, Nazareth, Ethiopia

Neri, F. 2001. Schooling Quality and Economic Growth; Economics Working Papers wp 01-06, School of Economics and Information Systems, University of Wollongong.

Pal, S. 2001. Child Schooling in Peru: Further Evidence from Sequential Analysis of School Progression. http://econwpa.wustl.edu:80/eps/lab/papers/0309/0309001.pdf

Ranjan, P. 2001. Credit Constraints and the Phenomenon of Child Labour, Journal of Development Economics 64, 81-102

Ranjan, P. 1999. An Economic Analysis of Child Labor', Economics Letters, 64: 99-105

Roberts, J. 2003. Poverty Reduction Outcomes in Education and Health Public Expenditure and Aid, Overseas Development Institute, London, Working Paper 210

Rosati, Furio C. and Rossi, Mariacristina. 2003. Children's Working Hours and School Enrollment: Evidence from Pakistan and Nicaragua (July 2003). CEIS Tor Vergata Research Paper Series No. 25. http://ssrn.com/abstract $=428520$

Seyoum, T. 1997. The Education of Women in Ethiopia. A Missing Piece in the Development Puzzle', The Ethiopian Journal of Education, Vol. XVII(2)

Shapiro, D and B O Tambashe. 2001 'Gender, Poverty, Family Structure, and Investments in Children's Education in Kinshasa, Congo', Economics of Education Review, 20, 359-75

Tansel, A. 1997. School Attainment, Parental Education and Gender in Côte D'Ivoire and Ghana', Economic Development and Cultural Change, 45(4): 825-56

Tietjen, K. 1998. The Demand for Primary Education in Rural Ethiopia, USAID, Health and Human Resource Analysis for Africa Technical Paper No. 87 
Woldehanna, T. 2000. Economic Analysis and Policy Implications of Farm and Off-Farm Employment: A Case Study in the Tigray Region of Northern Ethiopia, Mansholt Studies 18.

World Bank. 1996. Beyond Poverty: How Supply Factors Influence Girls' Education in Guinea: Issues and Strategies, Report No. 14488-GUI, World Bank Washington. 


\section{Appendix: Output of probit models estimations}

Table A1: Determinants of a child being in school: probit model (dep. var. = if the child is in school)

\begin{tabular}{|c|c|c|c|c|}
\hline & $(1)$ & (2) & (3) & $(4)$ \\
\hline & 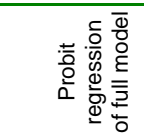 & 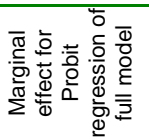 & 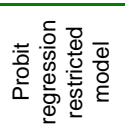 & 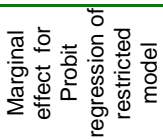 \\
\hline Dummy for male child & $\begin{array}{r}-0.109 \\
(1.19)\end{array}$ & $\begin{array}{r}-0.036 \\
(1.19)\end{array}$ & $\begin{array}{r}-0.106 \\
(1.16)\end{array}$ & $\begin{array}{r}-0.035 \\
(1.16)\end{array}$ \\
\hline Dummy for Amhara Region & $\begin{array}{l}0.497^{*} \\
(1.89)\end{array}$ & $\begin{array}{r}0.148^{\star} \\
(1.89)\end{array}$ & $\begin{array}{r}0.487^{\star \star \star *} \\
(3.58)\end{array}$ & $\begin{array}{r}0.146^{\star \star \star} \\
(3.58)\end{array}$ \\
\hline Dummy for Oromia Region & $\begin{array}{r}-0.030 \\
(0.14)\end{array}$ & $\begin{array}{r}-0.010 \\
(0.14)\end{array}$ & & \\
\hline Dummy for SNNP Region & $\begin{array}{r}-0.296 \\
(1.37)\end{array}$ & $\begin{array}{r}-0.102 \\
(1.37)\end{array}$ & $\begin{array}{r}-0.227^{\star} \\
(1.79)\end{array}$ & $\begin{array}{r}-0.078^{\star} \\
(1.79)\end{array}$ \\
\hline Dummy for Tigray Region & $\begin{array}{r}-0.128 \\
(0.53)\end{array}$ & $\begin{array}{r}-0.043 \\
(0.53)\end{array}$ & & \\
\hline Dummy for urban residence & $\begin{array}{l}0.380^{*} \\
(1.89)\end{array}$ & $\begin{array}{l}0.123^{\star} \\
(1.89)\end{array}$ & $\begin{array}{c}0.382^{\star} \\
(1.94)\end{array}$ & $\begin{array}{l}0.123^{\star} \\
(1.94)\end{array}$ \\
\hline Wealth index consumer durable & $\begin{array}{r}3.205^{\star \star \star} \\
(4.86)\end{array}$ & $\begin{array}{r}1.062^{\star \star \star} \\
(4.86)\end{array}$ & $\begin{array}{r}3.244^{\star \star \star} \\
(5.07)\end{array}$ & $\begin{array}{r}1.075^{\star \star \star} \\
(5.07)\end{array}$ \\
\hline HH Size below 5 yrs old & $\begin{array}{l}0.027 \\
(0.46)\end{array}$ & $\begin{array}{l}0.009 \\
(0.46)\end{array}$ & & \\
\hline $\mathrm{HH}$ Size $\mathrm{b} / \mathrm{n}$ the age of 5 and 15 & $\begin{array}{r}-0.083^{*} \\
(1.92)\end{array}$ & $\begin{array}{r}-0.028^{*} \\
(1.92)\end{array}$ & $\begin{array}{r}-0.077^{\star} \\
(1.82)\end{array}$ & $\begin{array}{r}-0.026^{\star} \\
(1.82)\end{array}$ \\
\hline HH Size above the age of 15 & $\begin{array}{r}-0.099^{* \star} \\
(2.47)\end{array}$ & $\begin{array}{r}-0.033^{\star \star} \\
(2.47)\end{array}$ & $\begin{array}{r}-0.092^{\star \star} \\
(2.40)\end{array}$ & $\begin{array}{r}-0.030^{\star *} \\
(2.40)\end{array}$ \\
\hline Maximum Grades completed by Male members of a $\mathrm{HH}$ & $\begin{array}{r}0.035^{\star \star} \\
(2.32)\end{array}$ & $\begin{array}{r}0.012^{\star \star} \\
(2.32)\end{array}$ & $\begin{array}{r}0.037^{\star *} \\
(2.48)\end{array}$ & $\begin{array}{r}0.012^{\star \star} \\
(2.48)\end{array}$ \\
\hline Maximum Grades completed by Female members of a $\mathrm{HH}$ & $\begin{array}{r}0.053^{\star \star \star} \\
(3.17)\end{array}$ & $\begin{array}{r}0.018^{\star \star \star} \\
(3.17)\end{array}$ & $\begin{array}{r}0.052^{\star \star \star} \\
(3.13)\end{array}$ & $\begin{array}{r}0.017^{\star \star \star} \\
(3.13)\end{array}$ \\
\hline Dummy for male $\mathrm{HH}$ head & $\begin{array}{l}0.064 \\
(0.49)\end{array}$ & $\begin{array}{l}0.022 \\
(0.49)\end{array}$ & & \\
\hline Number of events that decreases the $\mathrm{HH}$ welfare & $\begin{array}{r}-0.056^{\star *} \\
(2.25)\end{array}$ & $\begin{array}{r}-0.019^{* *} \\
(2.25)\end{array}$ & $\begin{array}{r}-0.062^{\star *} \\
(2.49)\end{array}$ & $\begin{array}{r}-0.020^{\star *} \\
(2.49)\end{array}$ \\
\hline Cognitive Social Capital & $\begin{array}{r}0.141^{\star *} \\
(2.43)\end{array}$ & $\begin{array}{r}0.047^{\star *} \\
(2.43)\end{array}$ & $\begin{array}{r}0.138^{\star *} \\
(2.38)\end{array}$ & $\begin{array}{r}0.046^{\star *} \\
(2.38)\end{array}$ \\
\hline Absolute structural social capital & $\begin{array}{l}-0.058 \\
(1.21)\end{array}$ & $\begin{array}{r}-0.019 \\
(1.21)\end{array}$ & $\begin{array}{r}-0.087^{\star \star} \\
(2.19)\end{array}$ & $\begin{array}{r}-0.029 * * \\
(2.19)\end{array}$ \\
\hline \# of organization from which one get social support & $\begin{array}{r}-0.032 \\
(1.21)\end{array}$ & $\begin{array}{r}-0.011 \\
(1.21)\end{array}$ & & \\
\hline Citizenship & $\begin{array}{l}0.102 \\
(0.97)\end{array}$ & $\begin{array}{l}0.034 \\
(0.97)\end{array}$ & & \\
\hline Dummy for $\mathrm{HH}$ owns or rent land & $\begin{array}{r}0.544^{\star \star \star} \\
(3.16)\end{array}$ & $\begin{array}{r}0.184^{\star \star \star} \\
(3.16)\end{array}$ & $\begin{array}{r}0.517^{\star \star \star} \\
(3.12)\end{array}$ & $\begin{array}{r}0.175^{\star \star \star} \\
(3.12)\end{array}$ \\
\hline Dummy for the Ownership of livestock & $\begin{array}{r}-0.237^{*} \\
(1.91)\end{array}$ & $\begin{array}{r}-0.076^{*} \\
(1.91)\end{array}$ & $\begin{array}{r}-0.223^{\star} \\
(1.83)\end{array}$ & $\begin{array}{r}-0.072^{*} \\
(1.83)\end{array}$ \\
\hline Dummy for a child being involved in paid work & $\begin{array}{r}-0.303^{\star \star *} \\
(1.97)\end{array}$ & $\begin{array}{r}-0.107^{\star \star} \\
(1.97)\end{array}$ & $\begin{array}{r}-0.318^{\star *} \\
(2.11)\end{array}$ & $\begin{array}{r}-0.113^{\star \star} \\
(2.11)\end{array}$ \\
\hline Number of hours a child spent on $\mathrm{HH}$ chores & $\begin{array}{r}-0.044^{\star \star} \\
(1.97)\end{array}$ & $\begin{array}{r}-0.015^{\star \star} \\
(1.97)\end{array}$ & $\begin{array}{r}-0.045^{\star \star} \\
(1.97)\end{array}$ & $\begin{array}{r}-0.015^{\star \star} \\
(1.97)\end{array}$ \\
\hline Mean distance(KM)to public and private primary schools1 & $\begin{array}{r}-0.062^{\star \star} \\
(2.38)\end{array}$ & $\begin{array}{r}-0.021^{\star \star} \\
(2.38)\end{array}$ & $\begin{array}{r}-0.055^{\star \star \star} \\
(2.61)\end{array}$ & $\begin{array}{r}-0.018^{\star \star \star} \\
(2.61)\end{array}$ \\
\hline Constant & $\begin{array}{r}-0.244 \\
(0.71)\end{array}$ & & $\begin{array}{r}-0.229 \\
(0.74)\end{array}$ & \\
\hline Observations & 1000 & 1000 & 1000 & 1000 \\
\hline Pseudo $\mathrm{R}^{2}$ & 0.215 & & 0.213 & \\
\hline Condition number & 14.7 & & 11.9 & \\
\hline Test of restriction & \multicolumn{4}{|c|}{$\begin{array}{l}\chi^{2}(5)=1.75 \\
\text { Prob }>\chi^{2}(5)=0.88\end{array}$} \\
\hline
\end{tabular}


Table A2: Determinants of a child being in school: probit model (dep. var. = if the child is in school) with mothers' and fathers' schooling as explanatory variables

\begin{tabular}{|c|c|c|c|c|}
\hline & (1) & $(2)$ & (3) & (4) \\
\hline & $\begin{array}{l}\text { Probit } \\
\text { regression of } \\
\text { full model }\end{array}$ & $\begin{array}{l}\text { Marginal effect } \\
\text { for Probit } \\
\text { regression of full } \\
\text { model }\end{array}$ & $\begin{array}{c}\text { Probit } \\
\text { regression of } \\
\text { restricted model }\end{array}$ & $\begin{array}{l}\text { Marginal effect } \\
\text { Probit } \\
\text { regression of } \\
\text { restricted model }\end{array}$ \\
\hline Dummy for male child & $\begin{array}{r}-0.100 \\
(1.10)\end{array}$ & $\begin{array}{r}-0.033 \\
(1.10)\end{array}$ & $\begin{array}{r}-0.090 \\
(0.99)\end{array}$ & $\begin{array}{r}-0.030 \\
(0.99)\end{array}$ \\
\hline Dummy for Amhara Region & $\begin{array}{r}0.533^{\star *} \\
(2.04)\end{array}$ & $\begin{array}{r}0.159^{\star *} \\
(2.04)\end{array}$ & $\begin{array}{r}0.552^{\star \star *} \\
(3.86)\end{array}$ & $\begin{array}{r}0.164^{\star * *} \\
(3.86)\end{array}$ \\
\hline Dummy for Oromia Region & $\begin{array}{r}-0.021 \\
(0.10)\end{array}$ & $\begin{array}{r}-0.007 \\
(0.10)\end{array}$ & & \\
\hline Dummy for SNNP Region & $\begin{array}{r}-0.261 \\
(1.20)\end{array}$ & $\begin{array}{r}-0.090 \\
(1.20)\end{array}$ & $\begin{array}{r}-0.222^{\star} \\
(1.72)\end{array}$ & $\begin{array}{r}-0.077^{*} \\
(1.72)\end{array}$ \\
\hline Dummy for Tigray Region & $\begin{array}{r}-0.117 \\
(0.49)\end{array}$ & $\begin{array}{r}-0.040 \\
(0.49)\end{array}$ & & \\
\hline Dummy for urban residence & $\begin{array}{r}0.448^{* *} \\
(2.24)\end{array}$ & $\begin{array}{r}0.145^{\star \star} \\
(2.24)\end{array}$ & $\begin{array}{r}0.441^{\star *} \\
(2.24)\end{array}$ & $\begin{array}{r}0.143^{\star *} \\
(2.24)\end{array}$ \\
\hline Wealth index consumer durable & $\begin{array}{r}3.614^{* * *} \\
(5.41)\end{array}$ & $\begin{array}{r}1.208^{\star * *} \\
(5.41)\end{array}$ & $\begin{array}{r}3.570^{\star * *} \\
(5.61)\end{array}$ & $\begin{array}{r}1.195^{\star * *} \\
(5.61)\end{array}$ \\
\hline HH Size below 5 yrs old & $\begin{array}{l}0.021 \\
(0.38)\end{array}$ & $\begin{array}{l}0.007 \\
(0.38)\end{array}$ & & \\
\hline $\mathrm{HH}$ Size $b / n$ the age of 5 and 15 & $\begin{array}{r}-0.036 \\
(0.86)\end{array}$ & $\begin{array}{r}-0.012 \\
(0.86)\end{array}$ & & \\
\hline $\mathrm{HH}$ Size above the age of 15 & $\begin{array}{r}-0.032 \\
(0.82)\end{array}$ & $\begin{array}{r}-0.011 \\
(0.82)\end{array}$ & & \\
\hline Grades completed by the father of a child & $\begin{array}{l}0.006 \\
(0.32)\end{array}$ & $\begin{array}{l}0.002 \\
(0.32)\end{array}$ & & \\
\hline Grades completed by the mother of a child & $\begin{array}{l}0.025 \\
(1.21)\end{array}$ & $\begin{array}{l}0.008 \\
(1.21)\end{array}$ & $\begin{array}{l}0.025 \\
(1.27)\end{array}$ & $\begin{array}{l}0.008 \\
(1.27)\end{array}$ \\
\hline Dummy for male $\mathrm{HH}$ head & $\begin{array}{l}0.076 \\
(0.55)\end{array}$ & $\begin{array}{l}0.026 \\
(0.55)\end{array}$ & & \\
\hline $\begin{array}{l}\text { Number of events that decreases the } \mathrm{HH} \\
\text { welfare }\end{array}$ & $-0.056^{\star \star}$ & $-0.019 * \star$ & $-0.055^{\star \star}$ & $-0.019 * \star$ \\
\hline & $(2.27)$ & $(2.27)$ & $(2.24)$ & $(2.24)$ \\
\hline Cognitive Social Capital & $\begin{array}{r}0.133^{\star *} \\
(2.32)\end{array}$ & $\begin{array}{r}0.045^{\star *} \\
(2.32)\end{array}$ & $\begin{array}{r}0.130^{* *} \\
(2.25)\end{array}$ & $\begin{array}{r}0.043^{\star *} \\
(2.25)\end{array}$ \\
\hline Absolute structural social capital & $\begin{array}{r}-0.050 \\
(1.06)\end{array}$ & $\begin{array}{r}-0.017 \\
(1.06)\end{array}$ & $\begin{array}{r}-0.048 \\
(1.03)\end{array}$ & $\begin{array}{r}-0.016 \\
(1.03)\end{array}$ \\
\hline $\begin{array}{l}\text { \# of organization from which one get social } \\
\text { support }\end{array}$ & -0.030 & -0.010 & -0.026 & -0.009 \\
\hline 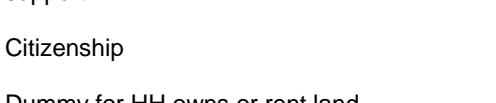 & $\begin{array}{l}(1.14) \\
0.101 \\
(0.97)\end{array}$ & $\begin{array}{l}(1.14) \\
0.034 \\
(0.97) \\
\end{array}$ & $(1.05)$ & $(1.05)$ \\
\hline Dummy for $\mathrm{HH}$ owns or rent land & $\begin{array}{r}0.528 * \star * \\
(3.10)\end{array}$ & $\begin{array}{r}0.180^{\star * *} \\
(3.10)\end{array}$ & $\begin{array}{r}0.511^{* * *} \\
(3.11)\end{array}$ & $\begin{array}{r}0.174 * \star * \\
(3.11)\end{array}$ \\
\hline Dummy for the Ownership of livestock & $\begin{array}{r}-0.247^{\star *} \\
(2.02)\end{array}$ & $\begin{array}{r}-0.080^{* \star} \\
(2.02)\end{array}$ & $\begin{array}{r}-0.217^{\star} \\
(1.79)\end{array}$ & $\begin{array}{r}-0.071^{*} \\
(1.79)\end{array}$ \\
\hline $\begin{array}{l}\text { Dummy for a child being involved in paid } \\
\text { work }\end{array}$ & $-0.285^{\star}$ & $-0.101^{*}$ & $-0.273^{\star}$ & $-0.097^{\star}$ \\
\hline Number of hours a child spent on $\mathrm{HH}$ chores & $\begin{array}{r}(1.88) \\
-0.050^{\star \star} \\
(2.25)\end{array}$ & $\begin{array}{r}(1.88) \\
-0.017^{\star \star} \\
(2.25)\end{array}$ & $\begin{array}{r}(1.82) \\
-0.052^{\star \star} \\
(2.34)\end{array}$ & $\begin{array}{r}(1.82) \\
-0.017^{\star \star} \\
(2.34)\end{array}$ \\
\hline $\begin{array}{l}\text { Mean distance }(\mathrm{KM}) \text { to public and private } \\
\text { primary schools1 }\end{array}$ & $-0.065^{\star \star}$ & $-0.022^{* *}$ & $-0.069^{* \star \star}$ & $-0.023^{\star * \star}$ \\
\hline Birth order & $(2.52)$ & $(2.52)$ & $\begin{array}{r}(3.04) \\
-0.054^{\star \star} \\
(2.05)\end{array}$ & $\begin{array}{r}(3.04) \\
-0.018^{\star *} \\
(2.05)\end{array}$ \\
\hline Constant & $\begin{array}{r}-0.274 \\
(0.80)\end{array}$ & & $\begin{array}{r}-0.151 \\
(0.49)\end{array}$ & \\
\hline Observations & 1000 & 1000 & 1000 & 1000 \\
\hline Pseudo $\mathrm{R}^{2}$ & 0.213 & & 0.203 & \\
\hline Condition number & 14.7 & & 11.9 & \\
\hline Test of restriction & \multicolumn{2}{|c|}{$\begin{array}{c}\chi^{2}(8)=3.52 \\
\text { Prob }>\chi^{2}(8)=0.897\end{array}$} & & \\
\hline
\end{tabular}


Table A3: Determinants of a child being enrolled in school by rural/urban residence (probit)

\begin{tabular}{|c|c|c|c|c|}
\hline & (1) & (2) & (3) & (4) \\
\hline & Urban & Rural & Urban & Rural \\
\hline \multirow[t]{2}{*}{ Dummy for male child } & 0.036 & -0.149 & -0.015 & -0.128 \\
\hline & $(0.18)$ & $(1.35)$ & $(0.08)$ & $(1.17)$ \\
\hline \multirow[t]{2}{*}{ Dummy for Amhara Region } & 0.746 & & 0.715 & \\
\hline & $(1.46)$ & & $(1.41)$ & \\
\hline \multirow{2}{*}{ Dummy for SNNP Region } & $-0.952^{\star * \star}$ & $-0.573^{\star \star}$ & $-0.857^{\star * \star}$ & $-0.534^{\star *}$ \\
\hline & (3.84) & $(2.52)$ & (3.64) & (2.35) \\
\hline \multirow[t]{2}{*}{ Wealth index consumer durable } & 1.252 & $5.465^{\star \star \star}$ & $2.040 * \star$ & $5.833^{\star * *}$ \\
\hline & $(1.39)$ & $(5.66)$ & $(2.28)$ & (5.98) \\
\hline \multirow[t]{2}{*}{ HH Size below 5 yrs old } & 0.120 & -0.017 & 0.104 & -0.020 \\
\hline & $(0.83)$ & $(0.25)$ & $(0.74)$ & $(0.30)$ \\
\hline \multirow[t]{2}{*}{$\mathrm{HH}$ Size $\mathrm{b} / \mathrm{n}$ the age of 5 and 15} & -0.061 & -0.071 & 0.015 & -0.039 \\
\hline & $(0.72)$ & $(1.35)$ & $(0.19)$ & $(0.77)$ \\
\hline \multirow[t]{2}{*}{ HH Size above the age of 15} & -0.050 & $-0.123^{\star \star}$ & 0.063 & -0.080 \\
\hline & $(0.66)$ & $(2.27)$ & $(0.84)$ & $(1.54)$ \\
\hline \multirow[t]{2}{*}{ Maximum Grades completed by Male members of a $\mathrm{HH}$} & 0.050 & 0.028 & & \\
\hline & $(1.59)$ & $(1.50)$ & & \\
\hline \multirow[t]{2}{*}{ Maximum Grades completed by Female members of a $\mathrm{HH}$} & $0.100 * * *$ & 0.032 & & \\
\hline & $(3.10)$ & $(1.46)$ & & \\
\hline \multirow[t]{2}{*}{ Dummy for male $\mathrm{HH}$ head } & 0.234 & 0.070 & 0.243 & 0.107 \\
\hline & $(0.99)$ & $(0.38)$ & $(0.88)$ & $(0.58)$ \\
\hline \multirow[t]{2}{*}{ Number of events that decreases the $\mathrm{HH}$ welfare } & $0.118^{*}$ & $-0.063^{\star \star}$ & 0.105 & $-0.062^{\star \star}$ \\
\hline & $(1.73)$ & $(2.11)$ & $(1.55)$ & $(2.08)$ \\
\hline \multirow[t]{2}{*}{ Cognitive Social Capital } & 0.030 & $0.154^{* *}$ & -0.001 & $0.152^{* *}$ \\
\hline & $(0.24)$ & $(2.02)$ & $(0.01)$ & $(2.00)$ \\
\hline \multirow[t]{2}{*}{ Absolute structural social capital } & -0.013 & -0.063 & -0.007 & -0.054 \\
\hline & $(0.11)$ & $(1.09)$ & $(0.06)$ & $(0.93)$ \\
\hline \multirow[t]{2}{*}{ \# of organization from which one get social support } & -0.054 & -0.042 & -0.032 & -0.044 \\
\hline & $(0.70)$ & $(1.39)$ & $(0.42)$ & $(1.45)$ \\
\hline \multirow[t]{2}{*}{ Citizenship } & -0.043 & 0.141 & -0.030 & 0.137 \\
\hline & $(0.18)$ & $(1.11)$ & $(0.13)$ & $(1.08)$ \\
\hline \multirow[t]{2}{*}{ Dummy for $\mathrm{HH}$ owns or rent land } & 0.138 & $0.477^{\star \star}$ & 0.069 & $0.483^{\star *}$ \\
\hline & $(0.32)$ & $(2.22)$ & $(0.17)$ & $(2.25)$ \\
\hline \multirow[t]{2}{*}{ Dummy for the Ownership of livestock } & $-0.514^{\star *}$ & -0.121 & $-0.534^{\star *}$ & -0.115 \\
\hline & $(2.32)$ & $(0.70)$ & $(2.49)$ & $(0.67)$ \\
\hline \multirow[t]{2}{*}{ Dummy for a child being involved in paid work } & 0.019 & $-0.302^{\star}$ & 0.196 & -0.288 \\
\hline & $(0.03)$ & $(1.72)$ & $(0.33)$ & $(1.64)$ \\
\hline \multirow[t]{2}{*}{ Number of hours a child spent on $\mathrm{HH}$ chores } & -0.020 & $-0.054^{\star \star}$ & -0.060 & $-0.056^{* *}$ \\
\hline & $(0.28)$ & $(2.12)$ & $(0.86)$ & $(2.20)$ \\
\hline \multirow[t]{2}{*}{ Mean distance(KM)to public and private primary schools1 } & 0.048 & $-0.057^{\star *}$ & 0.060 & $-0.060 * \star$ \\
\hline & $(0.40)$ & $(2.12)$ & $(0.53)$ & $(2.22)$ \\
\hline Dummy for Oromia Region & & $-0.662^{* * *}$ & & $-0.680^{\star * \star}$ \\
\hline & & $(3.41)$ & & (3.58) \\
\hline Dummy for Tigray Region & & $-0.916^{\star \star \star}$ & & $-0.959 * \star \star$ \\
\hline & & $(4.38)$ & & $(4.51)$ \\
\hline Grades completed by the father of a child & & & 0.002 & -0.018 \\
\hline & & & $(0.05)$ & $(0.74)$ \\
\hline Grades completed by the mother of a child & & & 0.042 & 0.032 \\
\hline & & & $(1.34)$ & $(0.98)$ \\
\hline Constant & 0.232 & 0.275 & 0.378 & 0.236 \\
\hline & $(0.39)$ & $(0.67)$ & $(0.66)$ & $(0.57)$ \\
\hline Observations & 350 & 600 & 350 & 600 \\
\hline Pseudo $\mathrm{R}^{2}$ & 0.226 & 0.113 & 0.181 & 0.107 \\
\hline
\end{tabular}


Table A4: Determinants of a child being enrolled in school by sex of child (probit model)

\begin{tabular}{|c|c|c|c|c|}
\hline & (1) & (2) & (3) & (4) \\
\hline & $\begin{array}{c}\text { Male } \\
\text { children }\end{array}$ & $\begin{array}{l}\text { Female } \\
\text { children }\end{array}$ & $\begin{array}{c}\text { Male } \\
\text { children }\end{array}$ & $\begin{array}{l}\text { Female } \\
\text { children }\end{array}$ \\
\hline \multirow{2}{*}{ Dummy for Amhara Region } & 0.440 & $0.806^{\star \star}$ & 0.449 & $0.648^{*}$ \\
\hline & $(1.23)$ & $(2.12)$ & $(1.24)$ & $(1.68)$ \\
\hline \multirow[t]{2}{*}{ Dummy for Oromia Region } & 0.141 & -0.151 & 0.146 & -0.237 \\
\hline & $(0.45)$ & $(0.45)$ & $(0.46)$ & $(0.69)$ \\
\hline \multirow[t]{2}{*}{ Dummy for SNNP Region } & 0.172 & $-0.674^{\star *}$ & 0.138 & -0.756 ** \\
\hline & $(0.59)$ & (2.19) & $(0.47)$ & $(2.37)$ \\
\hline \multirow{2}{*}{ Dummy for Tigray Region } & 0.012 & -0.217 & 0.079 & -0.325 \\
\hline & $(0.04)$ & $(0.59)$ & $(0.23)$ & $(0.86)$ \\
\hline \multirow[t]{2}{*}{ Dummy for urban residence } & $0.637^{\star \star}$ & 0.313 & $0.587^{\star \star}$ & 0.226 \\
\hline & $(2.14)$ & $(0.99)$ & $(1.96)$ & $(0.71)$ \\
\hline \multirow[t]{2}{*}{ Wealth index consumer durable } & $4.436^{\star \star \star}$ & $3.051^{\star * *}$ & $3.775^{\star \star \star}$ & $2.749 * \star *$ \\
\hline & $(4.90)$ & (3.33) & $(4.25)$ & $(2.95)$ \\
\hline \multirow[t]{2}{*}{ HH Size below 5 yrs old } & -0.046 & 0.064 & -0.063 & 0.083 \\
\hline & $(0.56)$ & $(0.76)$ & $(0.76)$ & $(0.97)$ \\
\hline \multirow[t]{2}{*}{$\mathrm{HH}$ Size $\mathrm{b} / \mathrm{n}$ the age of 5 and 15} & -0.087 & -0.013 & $-0.115^{\star}$ & -0.094 \\
\hline & $(1.49)$ & $(0.21)$ & $(1.90)$ & $(1.47)$ \\
\hline \multirow[t]{2}{*}{$\mathrm{HH}$ Size above the age of 15} & $-0.102^{*}$ & 0.031 & $-0.134^{\star \star}$ & -0.091 \\
\hline & $(1.81)$ & $(0.53)$ & $(2.28)$ & $(1.48)$ \\
\hline \multirow[t]{2}{*}{ Grades completed by the father of a child } & -0.024 & 0.048 & & \\
\hline & $(0.98)$ & $(1.60)$ & & \\
\hline \multirow[t]{2}{*}{ Grades completed by the mother of a child } & 0.007 & 0.048 & & \\
\hline & $(0.23)$ & $(1.35)$ & & \\
\hline \multirow[t]{2}{*}{ Dummy for male $\mathrm{HH}$ head } & $0.407^{*}$ & -0.202 & 0.301 & -0.080 \\
\hline & $(1.95)$ & $(1.00)$ & $(1.51)$ & $(0.41)$ \\
\hline \multirow[t]{2}{*}{ Number of events that decreases the $\mathrm{HH}$ welfare } & $-0.062^{\star}$ & -0.054 & $-0.061^{\star}$ & -0.056 \\
\hline & $(1.69)$ & $(1.41)$ & $(1.68)$ & $(1.43)$ \\
\hline \multirow[t]{2}{*}{ Cognitive Social Capital } & 0.113 & $0.161^{*}$ & 0.111 & $0.167^{\star}$ \\
\hline & (1.33) & $(1.78)$ & $(1.31)$ & $(1.78)$ \\
\hline \multirow[t]{2}{*}{ Absolute structural social capital } & $-0.166^{\star \star}$ & 0.053 & $-0.190^{* * *}$ & 0.064 \\
\hline & (2.37) & $(0.74)$ & (2.69) & $(0.88)$ \\
\hline \multirow{2}{*}{ \# of organization from which one get social support } & 0.018 & $-0.078^{*}$ & 0.017 & $-0.079^{*}$ \\
\hline & $(0.48)$ & $(1.92)$ & $(0.46)$ & $(1.92)$ \\
\hline \multirow[t]{2}{*}{ Citizenship } & -0.039 & $0.323^{\star *}$ & -0.018 & $0.292^{*}$ \\
\hline & $(0.27)$ & $(1.98)$ & $(0.13)$ & $(1.78)$ \\
\hline \multirow[t]{2}{*}{ Dummy for $\mathrm{HH}$ owns or rent land } & $0.515^{\star *}$ & $0.607^{\star *}$ & $0.501^{\star *}$ & $0.675^{\star *}$ \\
\hline & (2.03) & $(2.27)$ & $(1.97)$ & $(2.52)$ \\
\hline \multirow[t]{2}{*}{ Dummy for the Ownership of livestock } & -0.150 & $-0.380^{* \star}$ & -0.122 & $-0.404^{\star *}$ \\
\hline & $(0.87)$ & $(1.99)$ & $(0.71)$ & $(2.08)$ \\
\hline \multirow[t]{2}{*}{ Dummy for a child being involved in paid work } & -0.201 & -0.312 & -0.207 & -0.362 \\
\hline & $(0.93)$ & $(1.19)$ & $(0.96)$ & $(1.37)$ \\
\hline Number of hours a child spent on $\mathrm{HH}$ chores & $-0.060^{*}$ & -0.032 & -0.053 & -0.027 \\
\hline & $(1.79)$ & $(0.93)$ & $(1.59)$ & $(0.78)$ \\
\hline Mean distance(KM)to public and private primary schools1 & -0.027 & $-0.111^{\star * *}$ & -0.028 & $-0.107^{* * *}$ \\
\hline & $(0.78)$ & (2.89) & $(0.80)$ & $(2.78)$ \\
\hline Maximum Grades completed by Male members of a $\mathrm{HH}$ & & & 0.030 & $0.044^{*}$ \\
\hline & & & $(1.40)$ & $(1.88)$ \\
\hline Maximum Grades completed by Female members of a $\mathrm{HH}$ & & & 0.034 & $0.091^{\star \star \star}$ \\
\hline & & & $(1.44)$ & $(3.26)$ \\
\hline Constant & -0.453 & -0.324 & -0.408 & -0.196 \\
\hline & $(0.87)$ & $(0.61)$ & $(0.78)$ & $(0.36)$ \\
\hline Observations & 510 & 490 & 510 & 490 \\
\hline Pseudo $\mathrm{R}^{2}$ & 0.215 & 0.231 & 0.221 & 0.247 \\
\hline
\end{tabular}


Tassew, Alemu and Jones: Education choices in Ethiopia:...

Table A5: Determinants of a child being enrolled in school by region (probit)

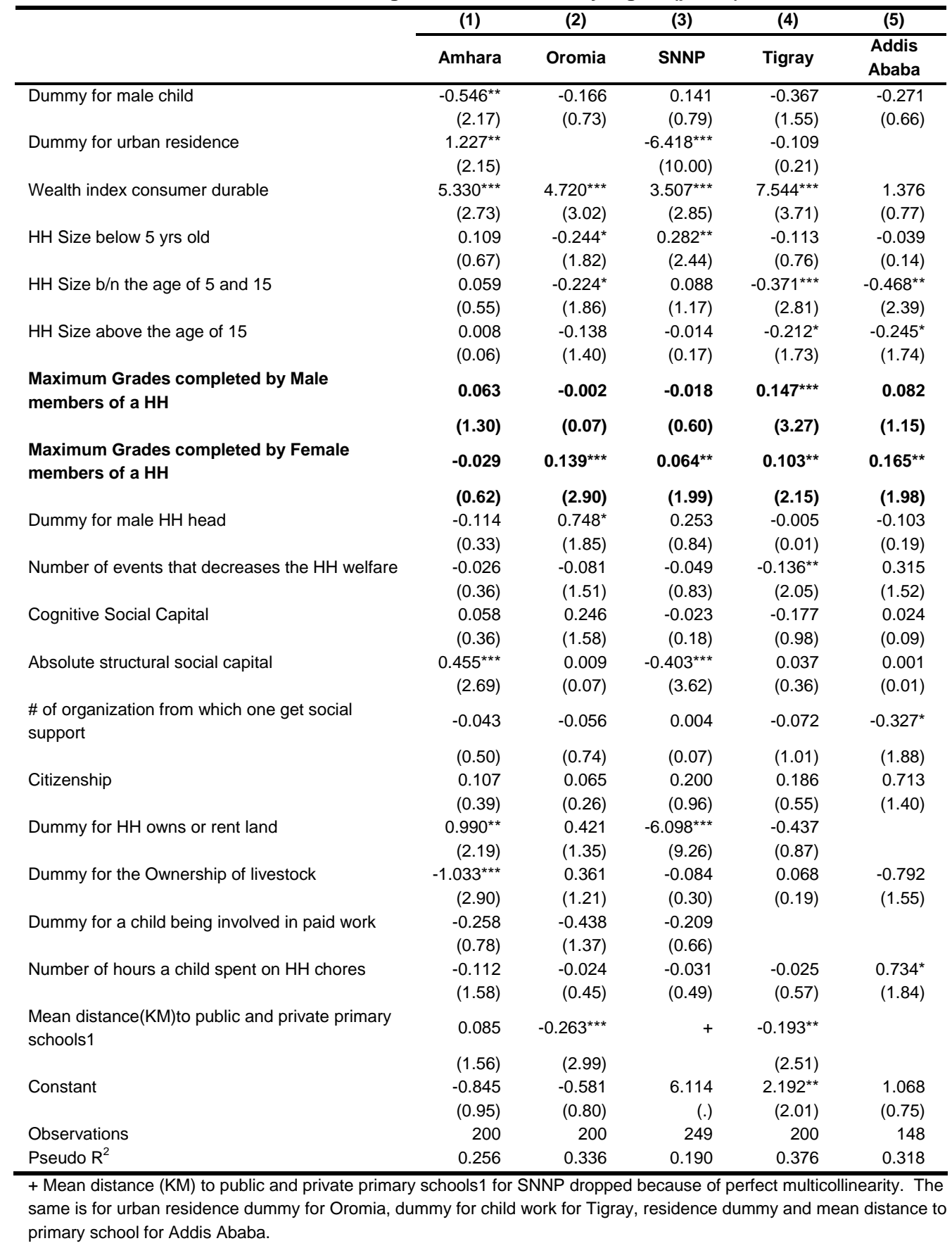


Table A6: Determinants of a child being enrolled in school by region (probit)

\begin{tabular}{|c|c|c|c|c|c|}
\hline & (1) & (2) & (3) & (4) & (5) \\
\hline & Amhara & Oromia & SNNP & Tigray & AA \\
\hline \multirow[t]{2}{*}{ Dummy for male child } & $-0.516^{\star \star}$ & -0.159 & 0.114 & -0.196 & -0.217 \\
\hline & $(2.08)$ & $(0.71)$ & $(0.63)$ & $(0.88)$ & $(0.59)$ \\
\hline \multirow[t]{2}{*}{ Dummy for urban residence } & $1.317^{\star \star}$ & & $-6.595^{\star \star \star}$ & 0.135 & \\
\hline & $(2.32)$ & & $(10.33)$ & $(0.27)$ & \\
\hline \multirow[t]{2}{*}{ Wealth index consumer durable } & $5.237^{\star \star}$ & $5.321^{\star \star *}$ & $3.656^{\star \star \star}$ & $7.717^{\star \star \star}$ & 2.502 \\
\hline & $(2.56)$ & (3.43) & (3.01) & $(4.02)$ & $(1.40)$ \\
\hline \multirow[t]{2}{*}{ HH Size below 5 yrs old } & 0.019 & -0.194 & $0.299 * * *$ & $-0.239^{*}$ & -0.075 \\
\hline & $(0.12)$ & $(1.49)$ & $(2.58)$ & $(1.72)$ & $(0.29)$ \\
\hline \multirow[t]{2}{*}{$\mathrm{HH}$ Size $\mathrm{b} / \mathrm{n}$ the age of 5 and 15} & 0.084 & -0.136 & 0.108 & -0.174 & $-0.353^{\star *}$ \\
\hline & $(0.83)$ & $(1.21)$ & $(1.46)$ & $(1.50)$ & $(2.06)$ \\
\hline \multirow[t]{2}{*}{$\mathrm{HH}$ Size above the age of 15} & 0.073 & -0.067 & 0.026 & -0.020 & -0.071 \\
\hline & $(0.66)$ & $(0.72)$ & $(0.29)$ & $(0.19)$ & $(0.61)$ \\
\hline \multirow[t]{2}{*}{ Grades completed by the father of a child } & 0.073 & -0.005 & -0.057 & 0.023 & 0.003 \\
\hline & (1.08) & $(0.12)$ & $(1.64)$ & $(0.27)$ & $(0.05)$ \\
\hline \multirow[t]{2}{*}{ Grades completed by the mother of a child } & 0.077 & 0.074 & $0.071^{*}$ & 0.093 & 0.009 \\
\hline & (1.03) & $(1.24)$ & $(1.73)$ & $(0.85)$ & $(0.16)$ \\
\hline \multirow[t]{2}{*}{ Dummy for male $\mathrm{HH}$ head } & -0.171 & 0.640 & 0.410 & 0.157 & 0.033 \\
\hline & $(0.49)$ & $(1.62)$ & $(1.24)$ & $(0.49)$ & $(0.06)$ \\
\hline \multirow[t]{2}{*}{ Number of events that decreases the $\mathrm{HH}$ welfare } & -0.028 & $-0.087^{*}$ & -0.051 & $-0.114^{*}$ & 0.241 \\
\hline & $(0.39)$ & $(1.66)$ & $(0.87)$ & $(1.83)$ & $(1.29)$ \\
\hline \multirow[t]{2}{*}{ Cognitive Social Capital } & 0.042 & $0.258^{*}$ & -0.040 & -0.086 & -0.068 \\
\hline & $(0.25)$ & (1.69) & $(0.31)$ & $(0.53)$ & $(0.30)$ \\
\hline \multirow{2}{*}{ Absolute structural social capital } & $0.455^{\star \star *}$ & 0.013 & $-0.415^{\star \star \star}$ & 0.013 & 0.056 \\
\hline & $(2.62)$ & $(0.10)$ & (3.63) & $(0.13)$ & $(0.27)$ \\
\hline \multirow[t]{2}{*}{$\begin{array}{l}\text { \# of organization from which one get social } \\
\text { support }\end{array}$} & -0.061 & -0.045 & -0.003 & -0.065 & -0.211 \\
\hline & $(0.70)$ & $(0.61)$ & $(0.06)$ & $(0.95)$ & $(1.33)$ \\
\hline \multirow[t]{2}{*}{ Citizenship } & 0.044 & 0.071 & 0.185 & 0.169 & 0.543 \\
\hline & $(0.16)$ & $(0.29)$ & $(0.89)$ & $(0.52)$ & $(1.26)$ \\
\hline \multirow[t]{2}{*}{ Dummy for $\mathrm{HH}$ owns or rent land } & $1.076^{\star *}$ & 0.268 & $-6.281^{\star \star \star}$ & -0.390 & \\
\hline & $(2.36)$ & $(0.90)$ & $(9.54)$ & $(0.82)$ & \\
\hline \multirow[t]{2}{*}{ Dummy for the Ownership of livestock } & $-1.032^{\star \star *}$ & 0.374 & -0.065 & 0.024 & -0.665 \\
\hline & $(2.89)$ & (1.29) & $(0.23)$ & $(0.07)$ & $(1.49)$ \\
\hline \multirow[t]{2}{*}{ Dummy for a child being involved in paid work } & -0.306 & -0.483 & -0.153 & & \\
\hline & $(0.91)$ & (1.49) & $(0.48)$ & & \\
\hline \multirow[t]{2}{*}{ Number of hours a child spent on $\mathrm{HH}$ chores } & -0.102 & -0.035 & -0.044 & -0.042 & 0.406 \\
\hline & (1.43) & $(0.68)$ & $(0.71)$ & (1.01) & (1.19) \\
\hline \multirow[t]{2}{*}{$\begin{array}{l}\text { Mean distance }(\mathrm{KM}) \text { to public and private primary } \\
\text { schools1 }\end{array}$} & $0.094^{*}$ & $-0.246^{\star \star \star}$ & & $-0.192^{\star \star \star}$ & \\
\hline & (1.71) & (2.87) & & (2.68) & \\
\hline \multirow[t]{2}{*}{ Constant } & -0.973 & -0.654 & 6.316 & 1.596 & 1.529 \\
\hline & (1.08) & $(0.92)$ & (.) & (1.59) & (1.25) \\
\hline Observations & 200 & 200 & 249 & 200 & 148 \\
\hline
\end{tabular}


Table A7: Components of absolute structural social capital

\begin{tabular}{lc}
\hline \multicolumn{1}{c}{ Group type } & Percentage of caregivers who are members of the group \\
\hline Trade union & 4.1 \\
Community association & 16.5 \\
Women's group & 26.4 \\
Political group & 2.3 \\
Religious group & 37.8 \\
Credit group & 9.9 \\
Funeral group & 62.3 \\
Sports group & 0.5 \\
\hline
\end{tabular}

Table A8: Construction of wealth index

\begin{tabular}{ll}
\hline \multicolumn{1}{c}{ Components of index and score } & \multicolumn{1}{c}{ Contributing variables } \\
\hline $\mathrm{H}=$ Housing quality $(/ 4)$ & Rooms/person, wall, roof, floor durability. \\
& Radio, fridge, bicycle, TV, motorbike/scooter, motor vehicle, \\
$\mathrm{CD}=$ Consumer Durables $(/ 11)$ & mobile phone, landline phone, modern bed, table or chair \\
& and sofa. \\
$\mathrm{S}=$ Services $(/ 4)$ & Electricity, water, sanitation, cooking fuel. \\
Wealth Index $=(\mathrm{H}+\mathrm{CD}+\mathrm{S}) / 3$ & Range $=0.0-1.0$ \\
\hline
\end{tabular}

\section{Table A9: Definition of social capital YL uses}

Four types of social capital were measured, namely, absolute structural social capital, social support, cognitive social capital and citizenship each of which are described below. Absolute structural social capital (ASSC) is defined based on the number of groups to which the caregiver belongs. Absolute structural social capital is categorized as high if the number of groups to which the caregiver belongs is three or more; as medium if the number of groups is one to two and zero if the caregiver is not a member of any group. Social support (SS) type of social capital is based on whether or not the caregiver has received support (emotional, economic or other) from either groups or individuals, in the year before the survey. It is considered high if a caregiver gets help from five or more groups and medium if the caregiver gets help from one to four groups. Cognitive social capital (CSC) is based on the caregiver's perceptions of the local community. The index of cognitive social capital is a combination of the responses to the questions on whether the caregiver feels she/he is part of the community, whether she/he feels people in general can be trusted, whether she/he feels people would try and take advantage of her/him if they could, and whether she/he feels people generally get along with each other. If the caregiver's response is positive for at least three of these they have high cognitive social capital, medium if they give only one or two positive answers and if all questions are answered negatively, we categorized them as having no cognitive social capital. Citizenship (CIT) is based on whether or not the caregiver has worked with others in the community to address a common issue. The citizenship index looks at the questions about joining together to address common issues and/or talks with the local authority on problems of the community. This index is a dichotomous ( 0 or 1 ) variable. The index is given a value ' 1 ' if the caregiver either joins together with others to address common issues or talks with the local authority about problems in the community. Otherwise ' 0 ' was given. 